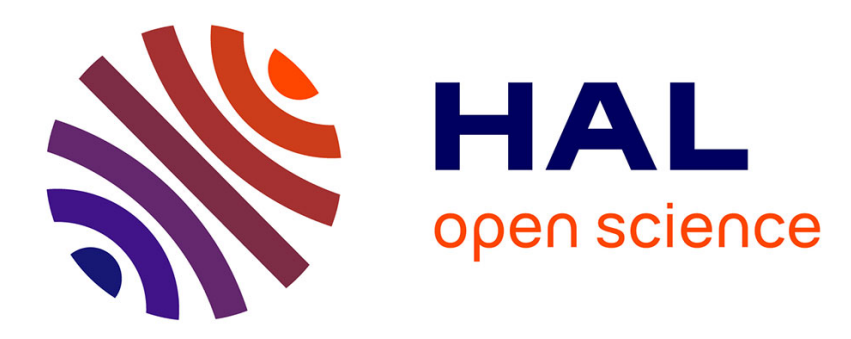

\title{
Cadmium minimization in rice. A review
}

Abin Sebastian, Majeti Prasad

\section{To cite this version:}

Abin Sebastian, Majeti Prasad. Cadmium minimization in rice. A review. Agronomy for Sustainable Development, 2014, 34 (1), pp.155-173. 10.1007/s13593-013-0152-y . hal-01234779

\section{HAL Id: hal-01234779 https://hal.science/hal-01234779}

Submitted on 27 Nov 2015

HAL is a multi-disciplinary open access archive for the deposit and dissemination of scientific research documents, whether they are published or not. The documents may come from teaching and research institutions in France or abroad, or from public or private research centers.
L'archive ouverte pluridisciplinaire HAL, est destinée au dépôt et à la diffusion de documents scientifiques de niveau recherche, publiés ou non, émanant des établissements d'enseignement et de recherche français ou étrangers, des laboratoires publics ou privés. 


\title{
Cadmium minimization in rice. A review
}

\author{
Abin Sebastian • Majeti Narasimha Vara Prasad
}

Accepted: 19 April 2013 / Published online: 21 June 2013

(C) INRA and Springer-Verlag France 2013

\begin{abstract}
Cadmium (Cd) contamination of rice is found in areas irrigated by wastewater from mines. Cd contamination of rice fields can also result from the application of Cd-rich phosphate fertilizers. As a consequence, millions of tons of rice are discarded. In Asia, irrigated paddy-based cropping systems provide rice grains as food for about 2 billion people. A daily intake of $20-40 \mu \mathrm{g} \mathrm{Cd}$ from rice is reported in regions where rice is used as a food. Daily rice $\mathrm{Cd}$ intake leads to diseases such as bone mineralization. Hence, $\mathrm{Cd}$ minimization in rice is needed. This article reviews sustainable agriculture and molecular techniques that prevents $\mathrm{Cd}$ uptake in rice. Cadmium minimization can be done either by field remediation or change in plant functions. Organic farming decreases $\mathrm{Cd}$ uptake and remediates crop fields. $\mathrm{Cd}$ hyperaccumulator plants and $\mathrm{Cd}$ immobilizing microbes can be used for field remediation. $\mathrm{Cd}$ amount in rice can be controlled by gene families that code for putative transition metal transporters or metal chaperones and quantitative trait loci (QTL). Generation of Cd excluder rice is possible by transgenics.
\end{abstract}

Keywords Biogeochemistry · Ecophysiology ·

Phytotechniques $\cdot$ Cadmium transporters $\cdot$ Metal chelators · Cadmium responsive genes $\cdot$ Cadmium excluder rice

\section{Contents}

1. Introduction $\ldots \ldots \ldots \ldots \ldots \ldots \ldots \ldots \ldots \ldots$

1.1 Biogeochemical cycle of cadmium . . . . . . . . 1

2. Ecophysiology of cadmium uptake . ........... 3

2.1 Soil redox potential adjustments . . . . . . . . . 4

2.2 Soil $\mathrm{pH}$ and nutrient management ........... 4

2.3 Organic matter management .............. 5

2.4 Morphology of rice and cadmium uptake . . . . . . 5

2.5 Physiological biomarkers of cadmium . . . . . . . . 5

A. Sebastian · M. N. V. Prasad $(\bowtie)$

Department of Plant Sciences, University of Hyderabad,

Hyderabad 500046, India

e-mail: prasad_mnv@yahoo.com
3. Phytotechniques and sustainable field remediation $\ldots .6$

3.1 Soil amendments . . . . . . . . . . . . . 6

3.2 Phytoremediation . . . . . . . . . . . . . . . . . . .

3.3 Bioremediation . . . . . . . . . . . 8

4. Molecular perspectives in cadmium minimization . . . 9

4.1 Cadmium transporters and chelators . . . . . . . 9

4.2 Cadmium dependant genomic traits . . . . . . . . 10

4.3 Cadmium responsive genes in rice . . . . . . . . 10

4.4 Cadmium excluder rice . . . . . . . . . . 11

4.5 Biofortification . . . . . . . . . . . 12

5. Outlook .................... 13

\section{Introduction}

Cadmium (Cd) is a toxic trace element belongs to group II $\mathrm{B}$ of periodic table of elements. Cd accumulation pose serious health implications in human such as anemia, hypertension, cancer, cardiac failure, cerebrovascular infarction, emphysema, proteinuria, serious damage in lungs, renal dysfunction, cataract formation in eyes, and osteoporosis (Godt 2006; Satarug et al. 2003). Major route of Cd uptake in human is through daily intake of food stuffs that contain Cd (Satarug et al. 2003; Wani et al. 2007). Average daily intake of $\mathrm{Cd}$ is considered as $30 \mu \mathrm{g}$ that varies between populations (Figueroa 2008). Usage of $\mathrm{Cd}$ in industrial applications such as anticorrosive agents for aircraft, stabilizer in polyvinyl chloride (PVC) products, color pigments, neutron-absorber in nuclear power plants, and fabrication of nickel-cadmium batteries has resulted in the increase in demand of $\mathrm{Cd}$ (Cotuk et al. 2010; Nriagu and Pacyna 1998).

\subsection{Biogeochemical cycle of cadmium}

Biogeochemical cycle of $\mathrm{Cd}$ indicates that the metal is released into the environment as an anthropogenic pollutant while emission from natural sources such as volcanic activities, weathering of rocks, and soil erosion are locally 
limited (Adamu and Nganje 2010; WHO 1992) (Fig. 1). Nitrogen containing $\mathrm{Cd}$ compounds such as cadmium nitrate are also found in the environment as a result of reduction reaction of nitrate with metallic $\mathrm{Cd}$. Studies on contribution of automobiles to environmental $\mathrm{Cd}$ release found that plants accumulate $\mathrm{Cd}$ near traffic where source of $\mathrm{Cd}$ is zinc ( $\mathrm{Zn})$ containing additives in motor oil and $\mathrm{Zn}$ compounds use in vulcanization of rubber tires (Aslan et al. 2011; Lagerwerff and Specht 1970). Burning of coal, smelters of nickel-Cd batteries, and electroplating are also found to be routes of $\mathrm{Cd}$ emission into the atmosphere that could transfer $\mathrm{Cd}$ into soil as well as vegetation cover through wet or dry deposition (Schoeters et al. 2006). Runoff from waste piles of mines especially $\mathrm{Cd}, \mathrm{Zn}$, and $\mathrm{Pb}$ are considered among the major routes of $\mathrm{Cd}$ contamination of rice fields (Sandalio et al. 2001). Other routes of Cd entry into paddy soil are agricultural practices such as application $\mathrm{Cd}$ containing fungicides, super phosphate fertilizers, and $\mathrm{Cd}$ containing sewage sludge application in the rice field (WHO 1992; Wang et al. 2009). Studies on provisional tolerable weekly intake (PTWI) indicate that major food sources that contribute $\mathrm{Cd}$ to human diet are rice, wheat, starchy roots/tubers, mollusks, and shellfish (Baize et al. 2009; Figueroa 2008; Flick et al. 1971). Application of fertilizers, genotype of crop use for cultivation, crop rotation, and dietary deficiencies are also factors which influence human exposure to $\mathrm{Cd}$ (Figueroa 2008). Among a wide range of $\mathrm{Cd}$ polluting sources, repeated application of Cd-containing phosphate fertilizers and irrigation using $\mathrm{Cd}$-contaminated water releasing from mines are causing massive contamination of Cd in rice fields (Lugon-Moulin et al. 2006; Sandalio et al. 2001; Yang et al. 2006). In a well-documented incident of $\mathrm{Cd}$ poisoning, itai-itai disease spread in Toyama prefecture in Japan was through daily intake of rice grains which were harvested from areas irrigated with Cd-contaminated waste water release of mines (Kobayashi 1978). A recent report from China covers Cd contamination of 1700,000 ha of farmland in northern Guangdong province of China (Yang et al. 2006). Since rice grain contributes a diet rich in vitamins, minerals, and complex carbohydrates for half the world population, there is persistent demand for $\mathrm{Cd}$ minimization in rice. The search for reducing $\mathrm{Cd}$ in rice opens the need to explore scientific approaches to minimize $\mathrm{Cd}$ in rice plants and hence reduction in the amount of $\mathrm{Cd}$ in the grain (Fig. 2). Application of Cd minimization strategies essentially requires a better understanding of ecophysiology of $\mathrm{Cd}$ uptake that links $\mathrm{Cd}$ in soil with rice plant, feasible field remediation measures that prevent $\mathrm{Cd}$ uptake into rice,

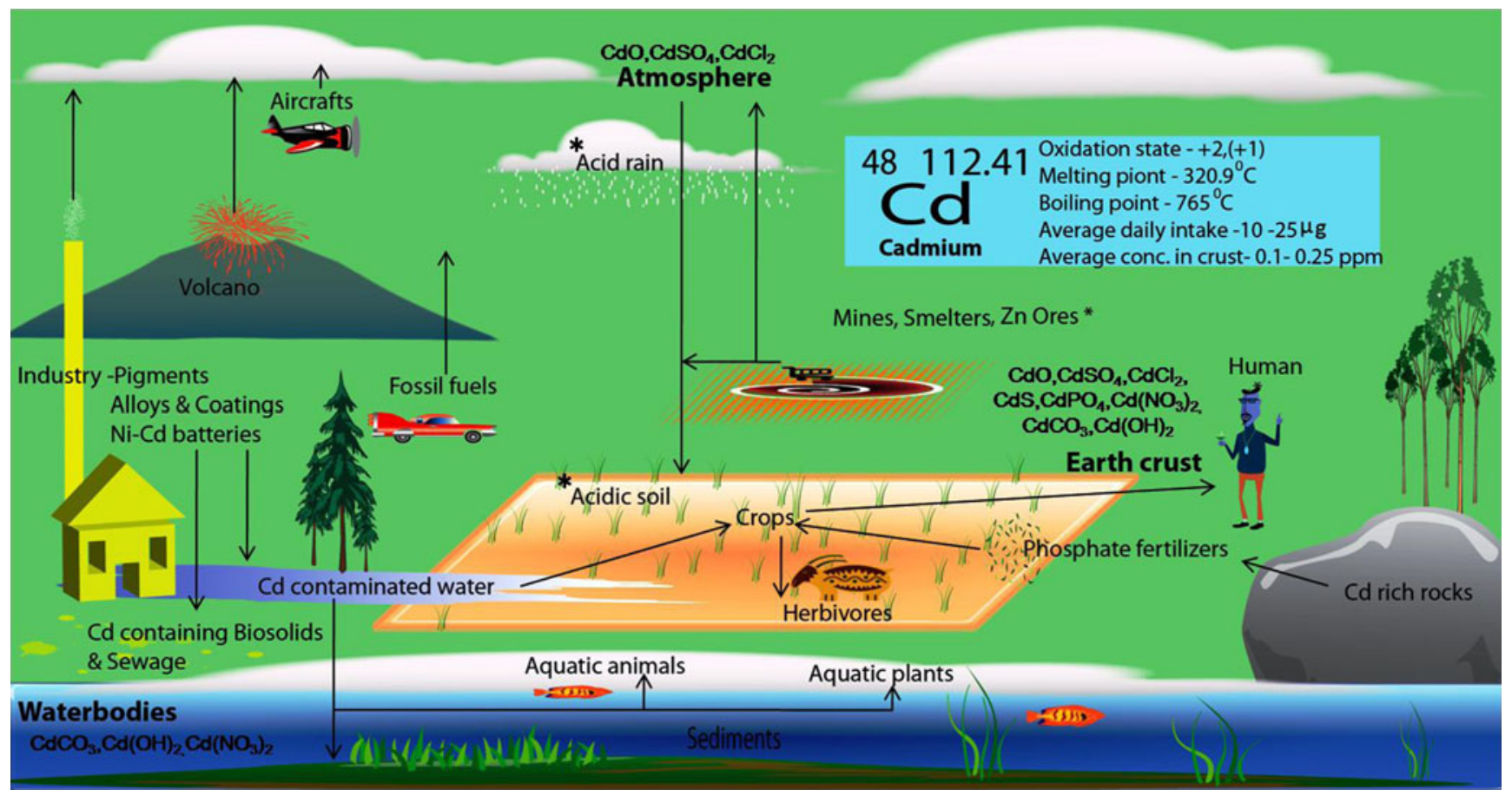

Fig. 1 Biogeochemical cycle of cadmium. Cadmium is a transition metal which is released into environment as a technogenic pollutant. It enters the atmosphere either by anthropogenic activities or natural sources like volcanoes. Entry of Cd from polluting source to the earth's crust can be direct or indirect by wet and dry precipitation of atmospheric Cd compounds. Cd contamination of water bodies occurs mainly via release of $\mathrm{Cd}$-rich water from various industrial sources as well as mine leachate. $\mathrm{Cd}$ occurs preferentially at different chemical forms in biosphere as indicated in the figure. Phosphate fertilizers produced from rock phosphate containing $\mathrm{Cd}$ are an inevitable source of $\mathrm{Cd}$ in rice field. The entry of $\mathrm{Cd}$ into humans is through the food chain while occupational exposure is negligible. *Acid rain as well as acidic soils have an influence on Cd uptake in vegetation by lowering soil $\mathrm{pH}$ which enhances $\mathrm{Cd}$ uptake by plants. Irrigation using water released from mines and smelters is the major route of massive $\mathrm{Cd}$ contamination in rice fields 


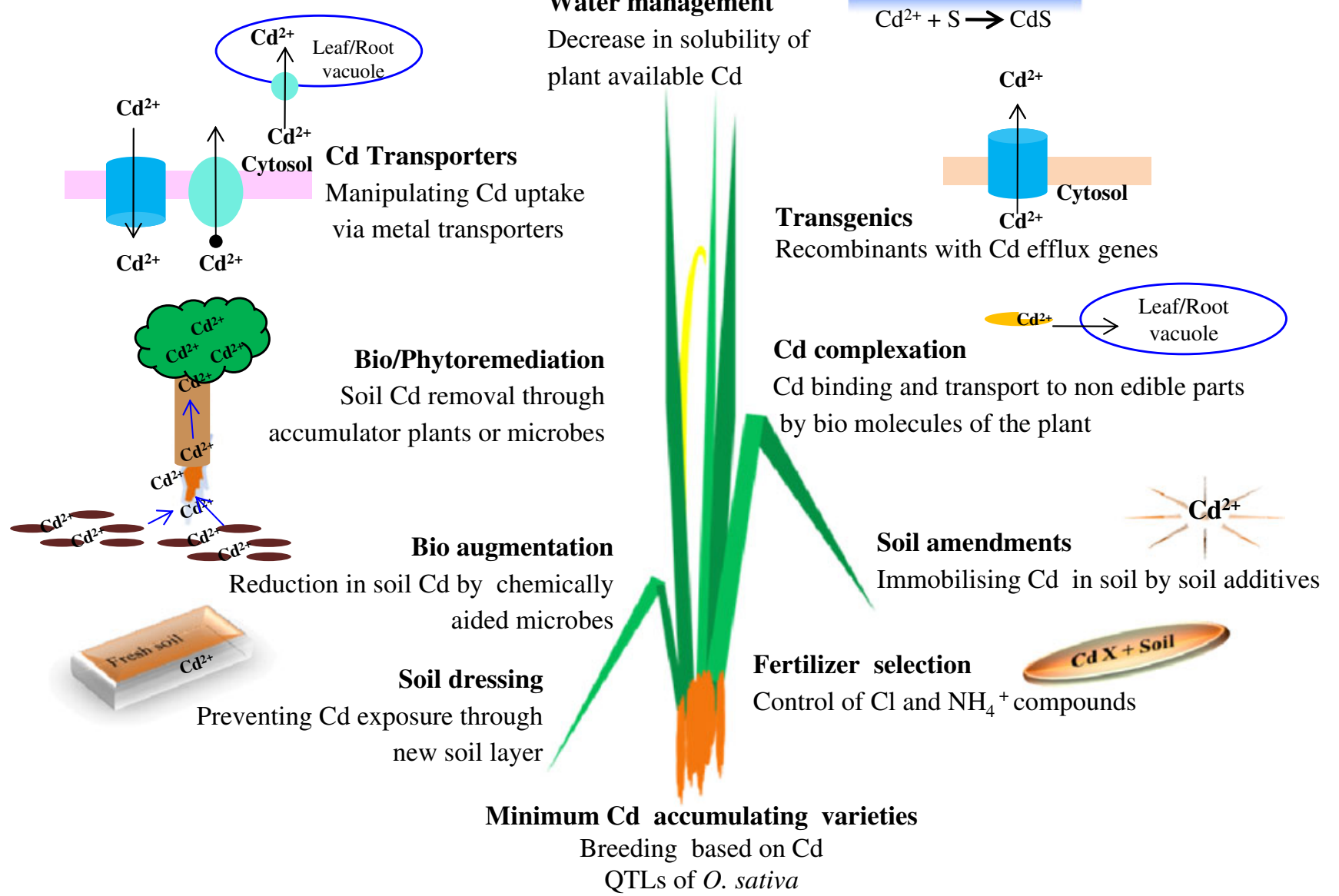

\section{Water management}

Decrease in solubility of plant available $\mathrm{Cd}$

Transgenics

$\mathrm{Cd}$ binding and transport to non edible parts

by bio molecules of the plant

Soil amendments

Immobilising $\mathrm{Cd}$ in soil by soil additives

Fertilizer selection

Control of $\mathrm{Cl}$ and $\mathrm{NH}_{4}{ }^{+}$compounds
Fig. 2 Strategies for cadmium minimization in rice. Water management keeps the reducing condition in field which allows $\mathrm{Cd}$ precipitation. Phytoremediation, soil amendments, bioaugmentation, and soil dressing are field remediation steps which are applicable prior to rice cultivation in the field. Manipulation of Cd-responsive metal transporters and use of genes of

and the factors affecting $\mathrm{Cd}$ uptake and partitioning in rice plants which are useful to generate rice plants resistant to $\mathrm{Cd}$. The following sections sequentially describe strategies to minimize $\mathrm{Cd}$ in rice.

\section{Ecophysiology of cadmium uptake}

Cadmium uptake by rice plant depends on ecophysiological components. Ecophysiological components belong to physical characters of field and morphological features of the plant. Physical components that influence $\mathrm{Cd}$ uptake are redox potential of the soil, soil $\mathrm{pH}$, essential trace element status, and organic matter content in the soil (Jung 2008; Matsi et al. 2007; Singh and Myhr 1998). These ecophysiological components promise various field management practices that can be utilized for minimizing $\mathrm{Cd}$ in rice (Fig. 3). Rice field development is characterized by dependence on field management irrespective of soil conditions prior to cultivation. Field management practices often lead such metal transporters allow exclusion of Cd from cytosol of roots as well as targeting $\mathrm{Cd}$ to vacuole in non-edible parts. $\mathrm{Cd}$ transport to the non-edible part of the plant can be accelerated through control of $\mathrm{Cd}$ complexation aided with metal chelators. Plant breeding focuses on quantitative trait loci (QTL) of $\mathrm{Cd}$ and breeding of rice varieties with lower $\mathrm{Cd}$ accumulation capacity

to specific soil horizon in lowland rice fields having four parts such as a top layer of water that forms plankton as well as microbial habitats, a zone with highly dynamic oxidation states, puddled layer characterized by lack of molecular oxygen, and plough pan where steady reducing state is maintained (Kögel-Knabner et al. 2010; McDonald et al. 2006). This kind of field management often leads to loss of clay particles during heavy rain runoff which creates disturbance in the soil profile (Garg et al. 2000; Gong 1983). A noticeable feature of such a rice field is redox dynamics that significantly affect uptake of $\mathrm{Cd}$ by rice (Cattani et al. 2008). Most of the growth period of rice is under anoxic condition whereas harvesting period is characterized by oxygenic condition which leads to an increase in redox potential of soil during which compounds of iron $(\mathrm{Fe})$ get oxidized (Magneschi and Perata 2009). Thus, puddled layer and the plough pan make a soil horizon characterized with reducing power formed through segregation of $\mathrm{Fe}$ and manganese (Mn) matrix, which could precipitate soluble fraction of Cd in soil (So and Ringrose-Voase 2000). 


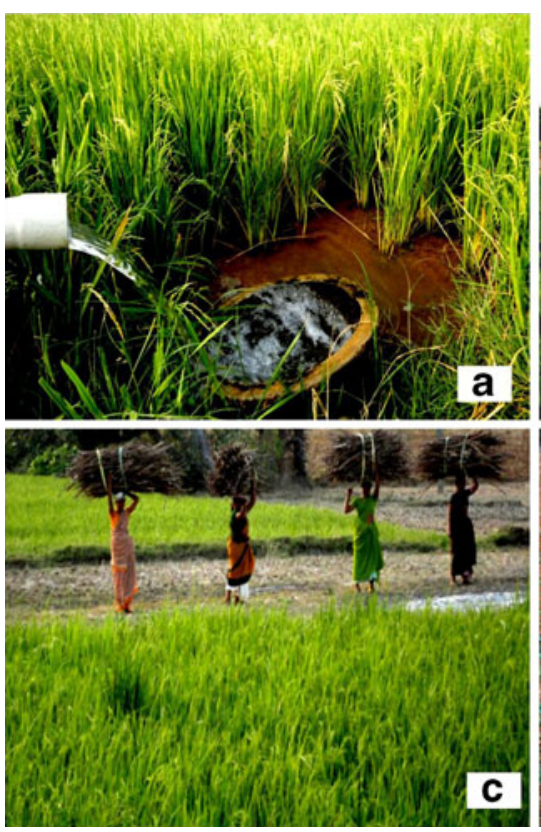

Fig. 3 Field managements for cadmium minimization in rice. a Essential water supply in the field ensures redox potential in the field and reduces $\mathrm{Cd}$ entry in to the rice by favoring $\mathrm{Cd}$ precipitation reactions. b Foliar micronutrient application especially at the time of tillering as well as grain maturation reduces the chance of nutrient deficiency adaptations such as release of phytosiderophores that favors Cd uptake. c Application of wood ash or biochar improves soil properties and replenishes

\subsection{Soil redox potential adjustments}

Soil redox potential adjustments help to control Cd solubility. Temporal and spatial changes in redox potential affect soil organic matter constituents and mineral constituents (Gallardo 2003). Cd solubility was found to decrease during reduction of soil suspension likely due to sorption to aluminum, $\mathrm{Fe}$, and/or Mn oxyhydroxides or precipitation of $\mathrm{CdS}$ or $\mathrm{CdCO}_{3}$ (Arao et al. 2009; Chlopecka 1996; Sarwar et al. 2010). Hence, it is important to have a flooding period before heading which significantly reduces $\mathrm{Cd}$ uptake into rice. A 16-fold reduction of $\mathrm{Cd}$ in rice was observed in a field trial where 8 days before heading period flooding was trialed (Arao et al. 2009). Formation of water-insoluble cadmium sulfide $(\mathrm{CdS})$ was attributed as the reason for decrease in Cd uptake in this study. On the other hand, when soil is drained, $\mathrm{Cd}$ forms cadmium sulfate $\left(\mathrm{CdSO}_{4}\right)$ which is soluble in water and causes higher uptake of $\mathrm{Cd}$ into rice. Chloride level in water is another concern which favors $\mathrm{Cd}$ uptake through the formation of exchangeable cadmium chloride $\left(\mathrm{CdCl}_{2}\right)$ complex (Smolders and McLaughlin 1996). Chlorosalinity also reduces soil sorption of $\mathrm{Cd}$ and increases $\mathrm{Cd}$ in the solution which leads to an increase in mobility and adsorption of Cd to roots (Liu et al. 2010; López-Chuken et al. 2010). Hence, chlorination of irrigation water must be under tight control to reduce $\mathrm{Cd}$ in rice. It is

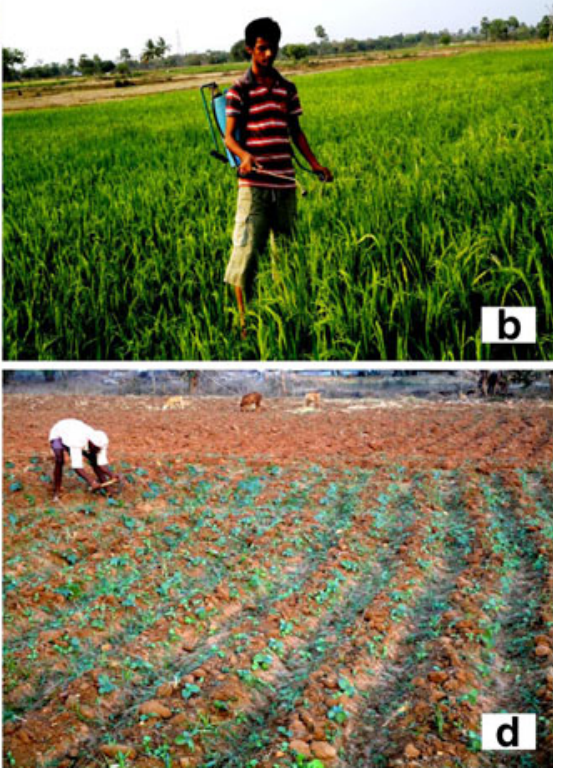

micronutrients in the field. This approach increases Cd-holding capacity of soil. Burning of wood in the field also has advantages in terms of destruction of various pathogens and spores of pathogen. $\mathbf{d}$ Crop rotation with legumes not only removes $\mathrm{Cd}$ in the field but also enhances nitrogen content and hence reduces requirement of ammonium-based nitrogen fertilizers decreasing soil $\mathrm{pH}$

noteworthy that control of application of potassium fertilizers based on potassium chloride $(\mathrm{KCl})$ that creates an increase in uptake of $\mathrm{Cd}$ by rice plants.

\subsection{Soil $\mathrm{pH}$ and nutrient management}

Soil $\mathrm{pH}$ and nutrient management allows lowering of $\mathrm{Cd}$ availability. Soil $\mathrm{pH}$ is featured as a key factor that controls the amount of exchangeable $\mathrm{Cd}$ in soil for plant uptake. Acidic soil was found to have more plant-exchangeable Cd (Appel et al. 2008; Sauvé et al. 2000). Cd adsorptive capacity of soils was reported to increase by a factor of three for one $\mathrm{pH}$ unit between $\mathrm{pH} 4.0$ and 7.7 (Christensen 1984). Soil $\mathrm{pH}$ changes in paddy fields are also uneven (KögelKnabner et al. 2010). During the early stage of crop growth, soil $\mathrm{pH}$ is neutral and turns into alkaline during the course of harvest. Consumption of proton often leads to an increase in soil $\mathrm{pH}$ of acidic soil under aerobic condition whereas flooding results in a decrease in soil $\mathrm{pH}$ due to $\mathrm{CO}_{2}$ production in rice fields (Kögel-Knabner et al. 2010). These point roles of increase in soil respiration that leads to an enhanced $\mathrm{Cd}$ uptake by rice. A high soil $\mathrm{pH}$ value usually favors sorption of $\mathrm{Cd}$ in soil which decreases partitioning of metal for plant uptake (Wang et al. 2006). Counter effect of industrial environmental pollution to soil $\mathrm{pH}$ and $\mathrm{Cd}$ uptake in rice plants could also be exemplified from the report that 
a 10-fold increase in plant-available $\mathrm{Cd}$ was a result of acid rain (Hutton et al. 1987).

Cadmium-holding capacity of top soil is usually higher, and the addition of biosolids often increases Cd-holding capacity as well as essential micronutrients which retard Cd uptake by plants (Hamon et al. 1998; Rate et al. 2004).Transfer of $\mathrm{Cd}$ from soil to plant also depends on the level of micronutrients such as $\mathrm{Zn}$, calcium (Ca), and magnesium (Mg) (Chaney et al. 2004; Haouari et al. 2012). Soil deficient in mineral nutrients has more exchangeable $\mathrm{Cd}$ and hence higher likelihood of uptake of $\mathrm{Cd}$ by plants. Phosphorous in the soil precipitates $\mathrm{Cd}$ by forming insoluble phosphate complexes (Street et al. 1978). Hence, if the field is deficient in phosphorous, application of diphosphate fertilizer devoid of $\mathrm{Cd}$ helps to reduce plant-available $\mathrm{Cd}$ in soil. It is better to use diphosphate than trisuperphosphate to reduce $\mathrm{Cd}$, which causes efficient sorption of $\mathrm{Cd}$ into the soil (McLaughlin et al. 1995). In nutrient-rich soil, phosphate has disadvantages in that it decreases $\mathrm{Zn}$ uptake which may lead to an enhancement in uptake of Cd by plants (Jiao et al. 2004; Root et al. 1973). It is reported that the presence of essential nutrients such as $\mathrm{Ca}, \mathrm{Zn}, \mathrm{Mn}, \mathrm{Fe}$, and copper $(\mathrm{Cu})$ was found to inhibit $\mathrm{Cd}$ uptake in plants (Cataldo et al. 1983; Sarwar et al. 2010). But these observations are controversial since nutrient uptake is controlled by multiple factors which may create paradoxical results. Agricultural practices for increasing yield through ammonium-based nitrogen fertilizers also lead to higher $\mathrm{Cd}$ uptake by rice because of soil acidification (Casova et al. 2009; Eriksson 1990). Hence, control of ammonium fertilizer must be done to avoid soil acidification which helps to prevent release of plant-available $\mathrm{Cd}$ in soil.

\subsection{Soil organic matter management}

Soil organic matter management help to prevent dynamics of soil Cd. Application of organic fertilizers such as farmyard manure, azolla manure, etc. improve the soil physical structure and could be an alternative to synthetic fertilizers. It is reported that abiotic and biotic factors such as soil $\mathrm{pH}$, anoxia, iron oxyhydroxides, clay minerals, aluminum hydroxides, and microbial communities play a significant role in determining the amount of organic matter especially soluble organic matter in natural paddy soils (KögelKnabner et al. 2010; Oyewole 2012). An increase in organic matter often affects soil $\mathrm{Cd}$ by adsorption of metal resulting in a decrease in plant-available $\mathrm{Cd}$ while weathering of organics in soil has a reverse effect (Brams and Anthony 1983). The presence of dissolved organic matter often increases the chance of reducing events. Hence, reducing condition that prevails after flooding through the incorporation of organic matter increases the chance of binding of $\mathrm{Cd}$ to organic matter and reduces plant-available $\mathrm{Cd}$ in soil
(Sauve et al. 2003). It is also observed that at higher soil $\mathrm{pH}$, organic matter forms soluble $\mathrm{Cd}$ complexes which make Cd unavailable for ion exchange process with roots (Adriano et al. 2004). Another factor of concern is removal of crop residues after harvest where residues after decomposition favor an increase in soil $\mathrm{Cd}$ level. Crop rotation with legume also has a significant role in determining plantavailable $\mathrm{Cd}$ level of the field. Soil surrounding legume rhizosphere is acidified through nitrogen fixation process and favors uptake of Cd by plant (Rao et al. 2002). Therefore, the growth of legume in the field helps to mobilize $\mathrm{Cd}$ and legumes remove $\mathrm{Cd}$ from the field by metal accumulation process. Mycorrhiza colonization was also reported to reduce uptake of $\mathrm{Cd}$ by creating a barrier before Cd entry into roots (Khan et al. 2000). Scope and application of mycorrhizae needs to be explored since rice plants do not have mycorrhizal association.

\subsection{Morphology of rice and cadmium uptake}

Morpho-physiological features of rice are in the direction of favoring uptake of $\mathrm{Cd}$. For example, rice being a monocot with fibrous root system that increases surface area for mineral absorption is favoring the chance of uptake of $\mathrm{Cd}$ (Coudert et al. 2010). Chelating agents such as organic acid from rhizospheric microbes and phytosiderophores from rice plants are favoring Cd uptake in rice (Romheld 1991). Solubilization of $\mathrm{Cd}$ by a cell-wall-mediated process is also described as a factor that increases the chance of Cd uptake by root cells (Clemens et al. 2002). A noticeable feature of rice is that plaque formed from iron and manganese which precipitate at root apoplast as a result of development of aeranchyma tissue. This tissue has higher redox potential during the course of submergence and makes $\mathrm{Cd}$ unavailable for translocation into shoot (Lui et al. 2008). It is noteworthy that the majority of $\mathrm{Cd}$ found in root resides at root apoplast and bind with cell wall polysaccharides (Zhang et al. 2009). Low diffusion coefficients of $\mathrm{Cd}$ in aqueous solution indicate that uptake of $\mathrm{Cd}$ into root depends on the transpiration pull and also point out the importance of water management in controlling $\mathrm{Cd}$ uptake (Hagemeyer et al. 1986; Lux et al. 2011).

\subsection{Physiological biomarkers of cadmium}

Physiological functions in plants are affected by $\mathrm{Cd}$ (Benavides et al. 2005; Hasan et al. 2009; Mediouni et al. 2006; Prasad 1995). Many of biotic as well as abiotic stress responses are also observed in Cd-induced stress (Gill and Tuteja 2011). One of the immediate responses of Cd toxicity is loss of plant pigments (Vassilev and Lidon 2011). Other processes such as photosynthesis, water use efficiency, and nutrient assimilation are also reported to be affected by $\mathrm{Cd}$ 
(Nazar et al. 2012; Tóth et al. 2012; Wahid et al. 2008). Among biochemical functioning; antioxidant enzyme pathways are extensively studied (Gill and Tuteja 2011; Shah et al. 2001; Wang et al. 2011). The influence of Cd on synthesis of cellular proteins such as rubisco, photosystem II, etc. points out the influence of $\mathrm{Cd}$ on sugar metabolism which ultimately affects overall growth of the plant because of the indirect relation of sugar metabolism with other cellular pathways such as aminoacid synthesis, fatty acid synthesis, etc. Thus, characterization of physiological functions in the presence of $\mathrm{Cd}$ helps to screen rice varieties for $\mathrm{Cd}$ tolerance as well as indicates the level of $\mathrm{Cd}$ contamination in the field. Since many physiological functions are under the control of quantitative loci, physiological monitoring aids to develop Cd-resistant varieties and approaches that are being taken for improving crop yield have an influence on $\mathrm{Cd}$ tolerance. Thus, crop improvement programs in rice should be monitored for Cd resistance too. In summary, ecophysiology of $\mathrm{Cd}$ uptake postulates field management practices such as artificial submergence and drainage, organic manuring, liming, and phosphate fertilization which are efficient to prevent $\mathrm{Cd}$ uptake. These practices are also found to affect redox status of the soil and hence help to control amount of exchangeable $\mathrm{Cd}$ in the soil. Crop morphology and physiological functions need to be matched for a low $\mathrm{Cd}$ accumulating trait.

\section{Phytotechniques and sustainable field remediation}

Removal of Cd or change of mobility $\mathrm{Cd}$ in soil is essential to prevent $\mathrm{Cd}$ entry into rice. Application of soil amendments, phytoremediation, and bioremediation are in use for large-scale field remediation programs (Chen et al. 2000; Lovley and Coates 1997). Key process in these methods are binding of $\mathrm{Cd}$ with amendment that results in the reduction of plant-available $\mathrm{Cd}$, removal of $\mathrm{Cd}$ from field using hyperaccumulator plants, and biosorption of metals or enzymatically catalyzed changes in redox state of metal by microbes respectively. An advantage of phytotechniques such as the use of organic amendments is that these amendments are ecofriendly as well as cost effective for use in large-scale field remediation (Fig. 4).

\subsection{Soil amendments}

Soil amendments are soil additives able to improve the physical characters of soil such as water-holding capacity, water permeability, water infiltration, aeration, and structure of soil (Madejón et al. 2006). The list of amendments that are reported to reduce $\mathrm{Cd}$ uptake in plants is given in Table 1. Most of the amendments work by reducing plantavailable $\mathrm{Cd}$ through phenomenon of sorption, adsorption, precipitation, immobilization, and stabilization of metal in the soil (Adriano et al. 2004; Wuana and Okieimen 2011). In case of organic amendments, periodic change of amended material must be done in order to back up metal-holding capacity after decomposition of the older one. Amendments mainly affect partitioning of $\mathrm{Cd}$ between solid and liquid phases of the soil. Sorption properties of organic amendments were found to have increased $\mathrm{Cd}$ binding properties of soil around 30 times than mineral soils (Save et al. 2003). Organic amendments form a coating over a particulate matter especially on surface and subsurface layers of soil and could act as metal binder. These amendments are characterized by the presence of lignin, cellulose, tannins, and
Fig. 4 Phytotech approaches for rice cultivation to minimize $\mathrm{Cd}$ accumulation. a Rhizofiltration of pollutants in water using Eichhornia crassipes (water hyacinth) prior to irrigation of crops removes heavy metals such as cadmium. b, c Cultivation of aquatic macrophytes such as Azolla pinnata enriches nitrogen fertilization and removes pollutants. d Farmyard manure (FYM) pit with cow dung covered by rice straw, a traditional practice for long-term storage of FYM. Application of FYM immobilizes $\mathrm{Cd}$ in soil with aid of humic/fulvic acids. Therefore, FYM usage as fertilizer prevents Cd loading in rice grain

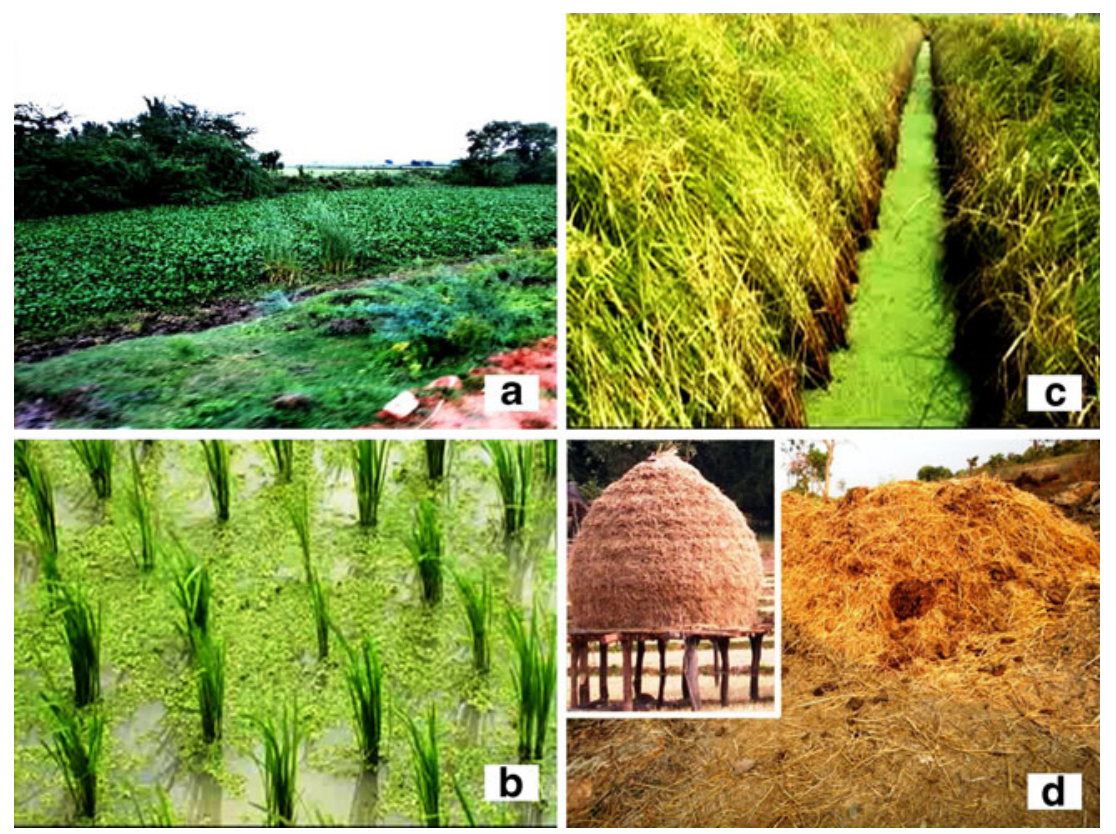


Table 1 Amendments used for remediation of cadmium-polluted sites

\begin{tabular}{|c|c|}
\hline Amendments & Reference \\
\hline Paper mill sludge & Battaglia et al. 2003 \\
\hline Fe/Mn oxide & Livera et al. 2011 \\
\hline Charcoal & Wang et al. 2010 \\
\hline Bentonite & $\begin{array}{l}\text { Karapinar and Donat 2009; } \\
\text { Fernández-Nava et al. } 2011\end{array}$ \\
\hline Perlite & Mathialagan and Viraraghavan 2002 \\
\hline Beringite & Adriano et al. 2004; Boisson et al. 1998 \\
\hline Clay minerals & Shirvani et al. 2007 \\
\hline Limestone & Basta and McGowen 2004 \\
\hline Mineral rock phosphate & Basta and McGowen 2004 \\
\hline Humus & Ok et al. 2011 \\
\hline Silica slag & Deja 2002 \\
\hline Lime & Ok et al. 2011 \\
\hline Gypsum & Poulsen and Dudas 1998 \\
\hline Hydroxyapatite & Boisson et al. 1999 \\
\hline Alkaline organic treatment & Bolan et al. 2003 \\
\hline Silicon & Kirkham 2006 \\
\hline Dolomite & Keller et al. 2005 \\
\hline Phosphate & Macaskie et al.1987 \\
\hline $\mathrm{K}_{2} \mathrm{HPO}_{4}$ & Adriano et al. 2004 \\
\hline $\mathrm{KH}_{2} \mathrm{PO}_{4}$ & Adriano et al. 2004 \\
\hline Poultry manure & Han et al.2008 \\
\hline Vermicompost & Pereira and Arruda 2003 \\
\hline Compost & McLaughlin et al.1995 \\
\hline Peat & Ma and Tobin 2003 \\
\hline Leaf litter & Adriano et al. 2004 \\
\hline Sewage sludge & Mahler et al. 1978; Baize 2008 \\
\hline Cattle manure & del Castilho et al. 1993 \\
\hline Elemental sulfur & Livera et al. 2011 \\
\hline Zeolite & Chlopecka and Adriano1997 \\
\hline Palygorskite & Wang et al. 2007 \\
\hline
\end{tabular}

carbonates that increase natural capability of soil to retain heavy metals (Berg 2000). An organic amendment treatment leads to an increase in dissolved organic carbon (DOC) in soil. Formations of stable soluble DOC-metal complexes have been reported to reduce readily available metal for plant uptake from soil (Han et al. 2001). The presence of metal complexing agents in dissolved organic amendments such as humic acids and fulvic acids increases efficiency of organic amendments to absorb metal. These polyelectrolytes are characterized by the abundance of carboxyl and hydroxyl groups that bind with Cd (Lee et al. 1993). Application of potential organic amendments such as seed powder of weeds also could act as donor of functional groups where functional groups such as carboxyl react with $\mathrm{Cd}$ and precipitate Cd in soil (Jayaram and Prasad 2009). Utilization of weeds and economically important plants such as bamboo which have potential to produce organic amendments for large-scale field remediation via utilization powder as well as charcoal prepared from plant parts that biosorb metals help sustainable field remediation (Lalhruaitluanga et al. 2010). Application of organic amendments in alkaline form also enhances carbon buffering of soil (Sloan and Basta 1995). Such treatments have the advantage that in addition to formation of $\mathrm{Cd}-$ carbonate precipitates and complexes, an increase of soil $\mathrm{pH}$ leads to sorption of $\mathrm{Cd}$ in soil. Exploitation of sewage as an organic amendment must be under monitoring because of the chance of Cd contamination in these materials (Moreno et al. 1999). Application of vermicompost, which appears to be ideal for Cd immobilization, is questionable where changes in soil structure upon addition of compost to soil such as increase in soil porosity enhance root growth (Sebastian and Prasad 2013). Enhanced root growth leads to $\mathrm{Cd}$ accumulation in rice plants by enhancing contact of root with $\mathrm{Cd}$. Another drawback of organic amendments is the degradation of raw materials and hence the need for periodic addition of the materials used for immobilizing metal in soil.

Synthetic compounds are more efficient compared to natural organic amendments because of purity and the possibility of modifying them for a better metal immobilization practice. Calcium and ammonium phosphate crop fertilizers are reported to have potential to serve as chemical immobilizers of heavy metals (Basta and McGowen 2004). Thus, fertilizer combinations having phosphorous as inorganic amendment assure immobilization of $\mathrm{Cd}$ in soil. The presence of sulfur is also important which was found to cope with Cd uptake under reducing conditions (Mendoza-Cózatl et al. 2003). The nitrification process during the course of ammonium fertilizer application is also reported to influence $\mathrm{Cd}$ immobilization process. An increase in $\mathrm{Cd}$ accumulation is found during the nitrification process upon diammonium phosphate treatments which have potential to immobilize Cd in soil (Levi-Minzi and Petruzzelli 1984; Pierzynski and Schwab 1993). Clay materials such as montmorillonite, palygorskite, kaolinite, bentonite, zeolites, sepiolite, perlite, etc. are another promising category of metal-adsorbing amendments which have been shown to have high adsorption capacity due to high specific surface area, high cation exchange capacity, high Brönsted and Lewis acidities, and flexible surface change against $\mathrm{pH}$ (Lin and Juang 2002; SuHsia and Reuy-Shin 2002). Drawbacks of some of these materials are formation of stable colloidal suspension upon infiltration by water and hence the decrease in permeability of the soil. This drawback could be overcome by pretreatments such as granulation (Fernández-Nava et al. 2011). Activated carbon is also a promising adsorbent for $\mathrm{Cd}$ in soil while cost effectiveness is a drawback. Calcium carbonate is widely used to increase $\mathrm{pH}$ and reported to decrease metal uptake by crops (Knox et al. 2001). Requirement of a 
large quantity of lime that must be repeated and shift in soil $\mathrm{pH}$ that affects essential nutrient uptake need to be considered during such lime treatments. Even though amendments are used widely to remediate field, the extent to which these materials can suppress metal uptake is debatable since they show variation in metal binding due to changes in soil properties.

Apart from amendments, physical methods in field management for $\mathrm{Cd}$ removal include methods such as soil dressing, soil washing, vitrification, chemical reduction, and electrokinetics (Bolan et al. 2013; Dermont et al. 2008). Thermal treatment, precipitation, sedimentation, ion exchange, reverse osmosis, and microfiltration are also applied in areas where large-scale contamination occurs. These methods are economically not feasible and recommended when contamination is at a higher extent. Washing of soil is usually performed with metal chelators such as ethylenediaminetetraacetic acid, triammonium bromide, calcium chloride, citric acid, hydrochloric acid, nitriloacetic acid, and other anionic biosurfactants (Huang et al. 1997).

\subsection{Phytoremediation}

Phytoremediation using hyperaccumulator plants are utilized to remove metal contaminants from soil (Prasad 2004). It is documented that introduction of metal-tolerant wild plants to metalliferous soils and genetic engineering of plants for enhanced synthesis for exudation of natural chelators into the rhizosphere are practical solutions to reduce exorbitant costs (Prasad and Freitas 1999). Selection of plant is critical in phytoremediation since surface area of root to soil contact plays a crucial role in metal accumulation. It is found that natural metal hyperaccumulator phenotypes are efficient in phytoremediation (Chaney et al. 1997; Prasad and Freitas 2002). Plants that belong to families such as Betulaceae, Brassicaceae, Carophyllaceae, Fabaceae, Fagaceae, Plumbaginaceae, and Poaceae are reported to accumulate toxic heavy metals where majority of them belong to Brassicaceae (Prasad and Freitas 1999a; 2002b). Fast growth rate and high biomass production rate are reported as key features of plants that must be taken into account during selection of a plant for phytoextraction (Pilon-Smits 2005; Schmidt 2003; Tang et al. 2003). Naturally growing grasses and weeds such as Cyperus rotundus, Cyperus kylinga, Marselia quadrifolia, and Ludwigia parviflora are reported to grow well in metalcontaminated sites and are useful in remediation of wetland rice fields (Sundaramoorthy et al. 2010). Plants such as Pteris vittata and Thlapsi caeruliensis that accumulate heav$\mathrm{y}$ metals are ideal choices for phytoextraction of $\mathrm{Cd}$ in upland rice fields (Ma et al. 2001; Milner and Kochian 2008; Zhao et al. 2003). Indian mustard, corn, sunflower, and sorghum are also reported to be effective in the remediation of metal-contaminated fields while the extent to which they can extract $\mathrm{Cd}$ from conventional rice fields needs to be explored (Jadia and Fulekar 2008). Remediation of fields using oil-producing crops such as sunflower have the advantage that they not only remediate field but also provide an opportunity to generate by-products such as biofuels that add up to the economy. An approach of rotating crop plants with hyperaccumulators is also ideal to prevent $\mathrm{Cd}$ contamination of rice. Removal of watersoluble $\mathrm{Cd}$ from lowland fields could be possible through phytoremediation using aquatic macrophytes such as Eichhornia crassipes, Lemna minor, and Pistia stratiotes which are proven efficient in rhizofiltration (Karkhanis et al. 2005). It is also found that growth of aquatic plants like Elatine hexandra, Althenia filiformis, and Monita rivularis in flooded rice fields potentially removes $\mathrm{Cd}$ from the soil (Robinson et al. 2001). Application of algal biomass in the flooded plain to remove $\mathrm{Cd}$ was also found to be effective 3fold compared to normal field conditions (Reniger 1977). Successive cropping and harvesting that reduces levels of contaminants in the soil is another approach where the removal of crop residues ensures periodic removal of metal contaminant (Vandenhove et al. 2001).

Phytoremediation accompanied by metal chelating molecules or symbiotic association such as mycorrhiza is another important tool in the process of phytoremediation (Prasad et al. 2010). Precipitation of $\mathrm{Cd}$ as polyphosphate granules in the soil, adsorption of $\mathrm{Cd}$ to chitin in fungal cell walls, and chelation of $\mathrm{Cd}$ inside fungus body are the chief characteristics of mycorrhiza-assisted soil cleanup (Joschim et al. 2009). The symbiotic interaction with hyphal network functionally extends root system and hence plants in symbiosis with mycorrhiza have more potential to take up metal from soil along with increase in water use efficiency and mineral uptake (Upadhyaya et al. 2010). Mycorrhiza association enhances essential mineral uptake especially phosphorous which has the ability to precipitate $\mathrm{Cd}$. Thus, mycorrhiza restricts entry of $\mathrm{Cd}$ into roots. Increase of biomass through mycorrhiza association also leads to tissue dilution effect of $\mathrm{Cd}$. This will reduce the amount of $\mathrm{Cd}$ which is able to reach the rice grain during grain maturation period (Wright et al. 1998). The potential of mycorrhiza to act as a filtration barrier against transfer of heavy metals to plants opens a scope of research to induce mycorrhiza association in rice plants.

\subsection{Bioremediation}

Application of microbial bioremediation is limited with regard to $\mathrm{Cd}$ minimization because $\mathrm{Cd}$ is not biodegradable. On the other hand, microbial immobilization of $\mathrm{Cd}$ and bioconversion of $\mathrm{Cd}$ complexes that limits metal availability to plantassisted phytoextraction are promising to remediate $\mathrm{Cd}$ contaminated rice fields. Microbial remediation of metal- 
contaminated sites depends on factors such as binding of $\mathrm{Cd}$ to cell walls, metal concentration, $\mathrm{pH}$, calcium concentration, ionic strength, and methylation of $\mathrm{Cd}$ (Christofi and Ivshina 2002; Vig et al. 2003). The carboxyl, phosphate, sulfhydryl, or hydroxyl functional groups acts as $\mathrm{Cd}$ adsorption sites on bacterial cell walls. This property makes microbial biomass to immobilize $\mathrm{Cd}$ in the field. Bacterial sorption of $\mathrm{Cd}$ was reported to be pronounced in sandy soil than in clay soil (Vig et al. 2003). It is reported that immobilized biosurfactantproducing bacteria Bacillus subtilis Tp8 and Pseudomonas fluorescens G9 remove Cd effectively from soil (Sarin and Sarin 2010). Sulfate-reducing bacteria which precipitate metal by forming metal sulfide are helpful in decreasing plantavailable $\mathrm{Cd}$. Application of alginate for soil inoculation of microbes is also promising to reduce exchangeable $\mathrm{Cd}$. Renewal of alginate beads must be done in such applications because mineralization of alginate will lead to release of bound Cd (Jézéque and Lebeau 2008).

Siderophore-producing bacteria are gaining attention to remove metals from contaminated sites because of higher efficiency to mobilize metal in the soil (Rajkumar et al. 2010). Bioaugmentation is another fast-growing phytotechnique that use microbes to enhance metal availability and mobility. It is reported that Pseudomonas fluorescens Pf 27, Variovorax paradoxus, Rhodococcus sp., and Flavobacterium sp. increase water-soluble and exchangeable $\mathrm{Cd}$ content in contaminated soil. This in turn enhanced both plant biomass and uptake of $\mathrm{Cd}$ of in Brassica juncea (Belimov et al. 2005; Fuloria et al. 2009). Similar observations were also found in case of soybean inoculated with Pseudomonas putida $62 \mathrm{BN}$ and Pseudomonas monteilli 97AN as well as canola inoculated with Pseudomonas tolaasii ACC23, Pseudomonas fluorescens ACC9, Alcaligenes sp. ZN4, and Mycobacterium sp. strains (Dell'Amico et al. 2008; Rani et al. 2009). Application of microbial fauna in rice field must be after field monitoring since rice plant is susceptible to various microbial pathogen attacks.

\section{Molecular perspectives in cadmium minimization}

Apart from field-based techniques, modifications in rice crop which restricts $\mathrm{Cd}$ uptake ensure food safety. This approach also reduces economic losses due to field remediation programs especially in fields which are moderately polluted with $\mathrm{Cd}$. It is reported that $\mathrm{Cd}$ uptake and allocation in various plant tissues are under control of genome (Fässler et al. 2011; Gallego et al. 2012). Cd tolerance in plants is also under control of genes which function by mediating metal chelator synthesis or exclusion of $\mathrm{Cd}$ through metal transporter mediated process (Clemens 2002; Hall and Williams 2003). Manipulation of these genes promises site-specific partitioning of $\mathrm{Cd}$ in plant tissues and hence controls the amount of $\mathrm{Cd}$ which may accumulate in the grain. Difference in occurrence of Cd controlling trait observed among rice varieties also postulates the scope of genomic level of control for $\mathrm{Cd}$ minimization in rice grains (Yan et al. 2010). Occurrence of Cd-dependent quantitative trait locus (QTL) allows screening of rice varieties that are able to resist $\mathrm{Cd}$ uptake or accumulate $\mathrm{Cd}$. Besides these, the search for genome via high throughput methods allows to find out Cd-responsive components in rice genome that help to develop rice plants with minimum uptake of $\mathrm{Cd}$.

\subsection{Cadmium transporters and metal chelators}

Cadmium transporters and metal chelators act as checkpoints in $\mathrm{Cd}$ uptake. $\mathrm{Cd}$, being a non-essential element for plant growth, limits existence of a Cd-specific transporter in plants. Membrane potential that reduces drastically in plasma membrane of root epidermal cells of rice and saturating nature of $\mathrm{Cd}$ uptake indicate the presence of secondary transporter-mediated $\mathrm{Cd}$ uptake which are essentially meant for micronutrient uptake (Llamas et al. 2000). Interaction of transporters and chelating agent necessary for metal uptake and storage also supports uptake of $\mathrm{Cd}$ through micronutrient transporters (Clemens et al. 2002). Families of transporters that mediate $\mathrm{Cd}$ uptake and transport reported include Zip and Nramp (broad range), ABC, Ysl, Copt, Heavy metal ATPases (CPX-type), $\mathrm{Ca}^{2+}$-ATPases, Cation $/ \mathrm{H}^{+}$antiporters, and GNGC (Clemens et al. 2002; Colangelo and Guerinot 2006; Hall and Williams 2003; Williams et al. 2000). Transporter families such as ZIP, COPT, and Nramp were found to be involved in Cd uptake while CDF family and $\mathrm{P}_{1} \mathrm{~B}$-ATPases mediate trafficking of $\mathrm{Cd}$ including $\mathrm{Cd}$ export from cytoplasm and delivery to metal chaperones, respectively (Lee et al. 2007; Shah and Nongkynrih 2007). With rice being graminacious, targeting of YS1 (OPT) is important in regulating metal uptake because of the chance of competition in Cd uptake with phytosiderophore-mediated iron assimilation (Curie and Briat 2003). Genes found in T. caeruliensis such as TcHMA4 are reported to play a role in xylem loading of Cd (Papoyan and Kochian 2004). It is beneficial to manipulate genes involved in xylem loading of $\mathrm{Cd}$ that helps to reduce metal uptake to the aerial parts. In a transgenic program which is utilizing metal transporters, the concept of genetically modified rice plants having metal exporters such as bacterial $\mathrm{ABC}$ transporters stands among primary targets while overexpression and silencing of transporters of interest to regulate $\mathrm{Cd}$ trafficking lies as a secondary choice. Regulation of Cd-specific transporter families at specific tissues will help to control passage of $\mathrm{Cd}$ into rice. One disadvantage of this approach is that blockage of broadrange substrate transporters that are involved in Cd uptake causes reduction in uptake of micronutrients too. 
Cadmium complexation in plants involves metal binding with chelating agents such as organic acids, small peptides, and metal-binding proteins (Saraswat and Rai 2011; Shah 2011). Most of the chelated toxic metals inside plants are targeting into vacuoles through metal detoxification process (Hall 2002; Haydon and Cobbett 2007). Exudates of root contain metal chelators which play a role in adjustment of rhizosphere $\mathrm{pH}$ and metal chelating process (Dong et al. 2007). A study with metal hyperaccumulators points out that chelators secreted by root result in an increase in plantavailable $\mathrm{Cd}$ whereas toxicity of $\mathrm{Cd}$ is alleviated by metalchelator complex formation (Callahan et al. 2006). Organic acids secreted from roots, e.g., malate, citrate, etc., are involved in metal uptake, long distance transport of metal, and transport of metal into vacuole (Jabeen et al. 2009; Verbruggen et al. 2009). It is found that chelators play a crucial role in keeping $\mathrm{Cd}$ in rice roots and form a barrier in $\mathrm{Cd}$ translocation (Nocito et al. 2011). Hence, controlled expression of Cd-inducible chelating agents such as phytochelatins, metallothionein, nicotianamine derivatives, etc. and targeting them to a non-edible part of the plant is important for preventing Cd entry into rice grain (Matsuda et al. 2009; Rauser 1999). Chelators are not favored in grains because of the ability to increase metal-holding capacity in grains.

\subsection{Cadmium-dependent genomic traits}

Difference in metal uptake and allocation observed among rice cultivars enable to develop rice varieties that limit $\mathrm{Cd}$ accumulation. Cd uptake and partitioning in rice is found under control of dominant traits which are heritable (Ishikawa et al. 2011; Kato et al. 2010; Ueno et al. 2011). It has been reported that there is a natural variation of about 13 23-fold difference in grain $\mathrm{Cd}$ concentration in diverse japonica rice germplasm (Arao and Ae 2003; Ueno et al. 2009). Characteristics found to influence $\mathrm{Cd}$ accumulation are high root activity, high shoot-to-root ratio, and water consumption (Hart et al. 1998; Ishikawa et al. 2010). Genetic background of QTLs identified with respect to $\mathrm{Cd}$ accumulation enables marker-assisted selection of genes that control low $\mathrm{Cd}$ trait in rice grain. Major QTLs controlling $\mathrm{Cd}$ accumulation are reported at chromosomes $2,7,3,4,6,8,5,11$, and 10 (Ishikawa et al. 2010; Ueno et al. 2009; Xue et al. 2009). Since the trait was found to be similar in lowland and upland conditions, low $\mathrm{Cd}$ trait will persist with regard to different environmental conditions. Utilization of low $\mathrm{Cd}$ trait allele will also help to minimize $\mathrm{Cd}$ concentration in grain along with little efforts for management practices (Grant et al. 2008). Hence, utilization of QTLs identified as low Cd trait in conjunction with economic traits must be in focus.

Genes identified in response to $\mathrm{Cd}$ in plants as well as microbes also open access to genetic recombination in rice for $\mathrm{Cd}$ minimization. Transformation of genes such as MT, CUP, gsh, APS, GR, OASTL, ArsC, GR, and ZntA was found to enhance Cd tolerance, and that of AtNramp and AtPCS resulted in Cd hypersensitivity in various model experimental plants (Cherian and Oliveira 2005; Ueno et al. 2010). But tolerance phenomenon does not stand for reduction in $\mathrm{Cd}$ content in plants and more or less useful for phytoremediation. Transformation and site-specific expression of P-type ATPase genes that code for metallochaperones is promising which helps to traffic $\mathrm{Cd}$ to non-edible parts of the rice plant. Transgenics using $\mathrm{Cd}$ efflux mechanism that operate through expression of operons controlling $C z c C, C z c B$, and $C z c A$ proteins in bacteria is another way to prevent entry of $\mathrm{Cd}$ into grains (Keller et al. 2005). Recombining with $\mathrm{CadA}$ or a gene that codes for $\mathrm{Cd}$ efflux ATPase and the $\mathrm{ABC}$ transporter AtPDR8, a Cd extrusion pump are also important to exclude the metal which entered into root (Kim et al. 2007; Silver 1996).

\subsection{Cadmium-responsive genes in rice}

A number of genes are reported in rice plants that relate with $\mathrm{Cd}$ uptake and tolerance (Table 2). Many of these genes are metal transporters which traffic Cd. Apart from metal transporters, genes that are specific to $\mathrm{Cd}$ signaling and tolerance are also reported. It is noteworthy that many of the $\mathrm{Cd}$ transporters are broad substrate range transporters that are able to transport essential trace elements such as $\mathrm{Mn}, \mathrm{Fe}$, and $\mathrm{Zn}$ in rice (Ishikawa et al. 2012; Ishimaru et al. 2012; Sasaki et al. 2012; Shimo et al.; 2011). This points to the complexity in modification of metal transporters for reduction in Cd uptake. An approach that pumps out specifically $\mathrm{Cd}$ from root is feasible to avoid deficiency of essential nutrients. Exploiting specific transporters that mediate phloem loading of $\mathrm{Cd}$ and translocation in phloem is important since grain filling is largely due to phloem loading. One of the drawbacks of ensuring $\mathrm{Cd}$ tolerance is that tolerance phenomenon does not account for reduction in $\mathrm{Cd}$ uptake. Tolerant varieties usually accumulate more cadmium unless tolerance operates by metal exclusion. Tissue dilution effect needs to be checked in such cases where tolerant varieties dilute amount of $\mathrm{Cd}$ accumulated with higher biomass production. A tolerant variety that produces higher biomass and accumulates more amount of $\mathrm{Cd}$ in tissues other than grain is preferred.

Cadmium signaling and metallothionein genes are related with maintaining redox balance in cells. These genes are operated as a response to alterations physiological process such as photosynthesis that assures reducing power (Reddy et al. 2004). Hence, the effect of these genes more or less occurs indirectly. For example, expression of MAPK kinases is due to Cdinduced reactive oxygen production and related oxidative stress (Pitzschke and Hirt 2006). Since production of metallothionein depends on the availability of sulfur, genes involved in sulfur metabolism are also indirectly related to Cd-inducible responses (Rauser 1999). Thus, expression of genes under $\mathrm{Cd}$ 
Table 2 Genes of rice reported to be regulated by cadmium

\begin{tabular}{|c|c|c|}
\hline Gene & Function & Reference \\
\hline OsNramp1, OsNramp 5 & $\mathrm{Cd}, \mathrm{Mn}$, and $\mathrm{Fe}$ transporter & Sasaki et al. 2012; Ishimaru et al. 2012 \\
\hline$O s L C D$ & $\mathrm{Cd}$ and $\mathrm{Mn}$ transporter & Shimo et al. 2011; Ishikawa et al. 2012 \\
\hline OsLCT1 & Cd transporter in phloem & Uraguchi et al. 2011 \\
\hline OsHMA2 & $\mathrm{Cd}$ and $\mathrm{Zn}$ translocation & Takahashi et al. 2012; Satoh-Nagasawa et al. 2012; Nocito et al. 2011 \\
\hline OsHMA3 & Sequestration of $\mathrm{Cd}$ in root & Takahashi et al. 2012; Ueno et al. 2010; Miyadate et al. 2011 \\
\hline OsCDT1-OsCDT5 & Cd uptake inhibitor & Kuramata et al. 2009 \\
\hline OsIRT1, OsIRT2 & $\mathrm{Cd}$ and iron transporter & Lee and An 2009; Nakanishi et al. 2006 \\
\hline OsNrampl & $\mathrm{Cd}$ accumulation in leaf & Uraguchi et al. 2011; Takahashi et al. 2011 \\
\hline OsYSL2 & Cd translocation & Masuda et al. 2012 \\
\hline OSISAP1 & Cd tolerance & Mukhopadhyay et al. 2004 \\
\hline OsMTP1 & Cd translocation & Yuan et al. 2012 \\
\hline Os HsfA4a, ricMT, rgMT & Cd tolerance via metallothionein & Shim et al. 2009; Yu et al. 1998; Hsieh et al. 1995 \\
\hline OsZIP1 & $\mathrm{Cd}$ and $\mathrm{Zn}$ transport & Ramesh et al. 2003; Chou et al. 2011 \\
\hline OsNAATl & Cd accumulation & Cheng et al. 2007 \\
\hline Ospdr9 & Redox protection in Cd stress & Moons 2003 \\
\hline$R C S 1$ & Cd complexation via sulfur & Harada et al. 2001 \\
\hline $\begin{array}{l}\text { OsMAPK2, OsMSRMK2 } \\
\text { OsMSRMK3, OsWJUMK1 }\end{array}$ & Cd signaling & Yeh et al. 2004; Agrawal et al. 2002 \\
\hline OsABCG43/PDR5 & Cd compartmentalization & Oda et al. 2011 \\
\hline$q C d T 7$ & Root-shoot translocation of Cd & Tezuka et al. 2010 \\
\hline PEZ1 & Cd accumulation & Ishimaru et al. 2011 \\
\hline OsHMA9 & Cd efflux & Lee et al. 2007 \\
\hline
\end{tabular}

stress is in a network that links metabolic pathways in cell and offers identification of a wide variety of genes that are regulated by $\mathrm{Cd}$ in the future. This dependency of cellular metabolism on $\mathrm{Cd}$ allows metabolic engineering of rice to cope with $\mathrm{Cd}$ toxicity. Overproduction of polyamines, phenolics, flavonols, and thiols are some of the metabolic compounds that must be targeted primarily in this aspect since these compounds alleviate Cd stress (Arvind and Prasad 2005).

\subsection{Cadmium excluder rice}

Since the development of Cd-tolerant plant leads to $\mathrm{Cd}$ accumulation rather than $\mathrm{Cd}$ exclusion, the concept of excluder plant arises. Generation of $\mathrm{Cd}$ excluding rice phenotype through genetic manipulation helps to block entry of $\mathrm{Cd}$ into rice plants. A Cd excluder rice plant will be able to survive in the presence of a higher concentration of $\mathrm{Cd}$ in soil while accumulating a lower amount of Cd. Naturally occurring $\mathrm{Cd}$ excluder phenotypes screened in rice cultivars indicate potential $\mathrm{Cd}$ excluding traits in rice genome and offer a vast opportunity for plant breeding to develop Cd excluder rice (Yu et al. 2006; Zhan et al. 2012). One of the disadvantages observed in excluder crops is weak grain production capacity. Thus, identification of $\mathrm{Cd}$ exclusion genes and its interaction with yield parameters are important for the development of excluder rice.
If the trait is localized as specific and non-polygenic, incorporation of $\mathrm{Cd}$ exclusion genes with increase in yield will be able to solve the issue of decreased yield in excluder rice. Transgenic approach could be either incorporation of genes responsible for $\mathrm{Cd}$ exclusion or complexing $\mathrm{Cd}$ within root. Techniques such as ion irradiation, activation tagging, marker-assisted breeding, etc. account for promising ways to locate genes that have a specific function such as $\mathrm{Cd}$ exclusion (Fig. 5). The first two methods mentioned are useful to develop mutants with desirable trait, i.e., minimization of $\mathrm{Cd}$ transport into the grain. Ion irradiation method makes use of energetic heavy-ion beams of charged particles such as carbon, neon, nitrogen, etc. which induce mutations with high frequency at a relatively low dose to plants (Tanaka et al. 2010). Activation tagging method is based on gain-of-function mutagenesis which may be either random insertion of transcriptional enhancers into the genome or expression of genes under the control of a strong promoter with the help of a transposon system (Gou and Li 2012; Lish 2002). Marker-assisted breeding helps to develop rice varieties from the mutants with the help of molecular markers that track the genetic makeup of plants (Collard and Mackill 2008). Thus, molecular techniques offer a vast opportunity to develop $\mathrm{Cd}$ excluder rice, but time period stands as a major drawback. 
a Cd responsive Protein $\longrightarrow$ MALDI TOF $\longrightarrow$ Identification of known gene $\downarrow$

Raising of antibody to precipitate

polysomes for collecting mRNA

cDNA synthesis and cloning

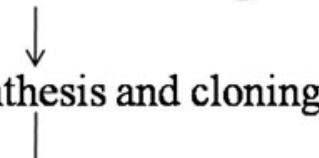

Microarray/Northern blot/ Reverse transcription

Colony hybridization with genomic DNA library

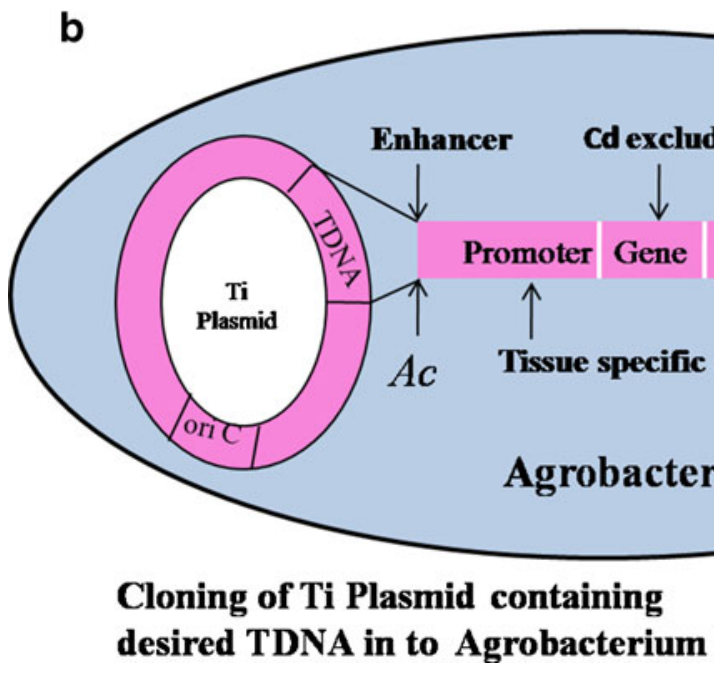

Fig. 5 Molecular tools and cadmium excluder rice. Cadmium (Cd)responsive genes can be isolated or identified from expressed protein or mRNA which are regulated during Cd stress in plants (Fig. 3a). Other methods such as map-based cloning, differential display, mutant complementation, substractive hybridization, etc. are also applicable to isolate Cd-specific genes. Once a desired gene is isolated, transgenic rice plant via classical transformation allows development of Cd excluder rice (Fig. 3b). Method such as activation tagging using enhancer sequence is useful for tagging Cd-responsive genes throughout the plant body or in a specific tissue with usage of a tissue-specific promoter and

\subsection{Biofortification}

Biofortification enriches micronutrients in cereal grains (Johns and Eyzaguirre 2007; Prasad 2008). Apart from this kind biofortification of rice grain, it may lead to constrained amount of grain $\mathrm{Cd}$ too. Biofortified crops having a capacity to specifically uptake and accumulate micronutrients limit entry of $\mathrm{Cd}$ into plant tissues (Prasad and Nirupa 2007; Prasad 2008; Zhao and Shewry 2011). Biofortification could be practiced through either usage of micronutrient fertilizers or genetic changes that enhance accumulation of micronutrients. Genetic approach is supported by the finding that transgenic tobacco carrying cDNA LTC1, a nonspecific transporter for $\mathrm{Ca}^{2+}, \mathrm{Cd}^{2+}, \mathrm{Na}^{+}$, hence identify Cd-responsive genes. In this method, addition of a tissuespecific promoter such as $O s G T 1$ (Wang et al. 2007b) also allows spatial expression of Cd-responsive genes whereas addition of a constitutive promoter such as CaMV5'S allows expression of the gene throughout the plant body. $A c-D s$ transposon vector system used in activation tagging has the advantage of requiring a minimal number of primary transformants and eliminates the need for crossing. Random mutagenesis methods such as tilling, ion beam irradiation, etc. also open the way to identify Cd-responsive genes as well as development of $\mathrm{Cd}$ excluder rice through marker-assisted breeding

and $\mathrm{K}^{+}$, displayed a substantially higher level of tolerance to $\mathrm{Cd}$ and accumulated less $\mathrm{Cd}$ in roots (Antosiewicz and Henning 2004). It is noteworthy that transgenic approaches to increase micronutrient content of cereal grains often need manipulation of metal transporters. Similarity in both uptake and allocation pattern of $\mathrm{Cd}$ with micronutrients such as $\mathrm{Zn}$ raises the possibility of technical problems in biofortification such as an increase of $\mathrm{Cd}$ content because of manipulation in transporters that are meant for $\mathrm{Zn}$ also reflect an increase in $\mathrm{Cd}$ uptake (Kramer 2010; Palmgren et al. 2008). On the other hand, boosting of field micronutrients level creates competition in uptake of $\mathrm{Cd}$ with micronutrients and hence possibility of reduction in $\mathrm{Cd}$ uptake exists. 


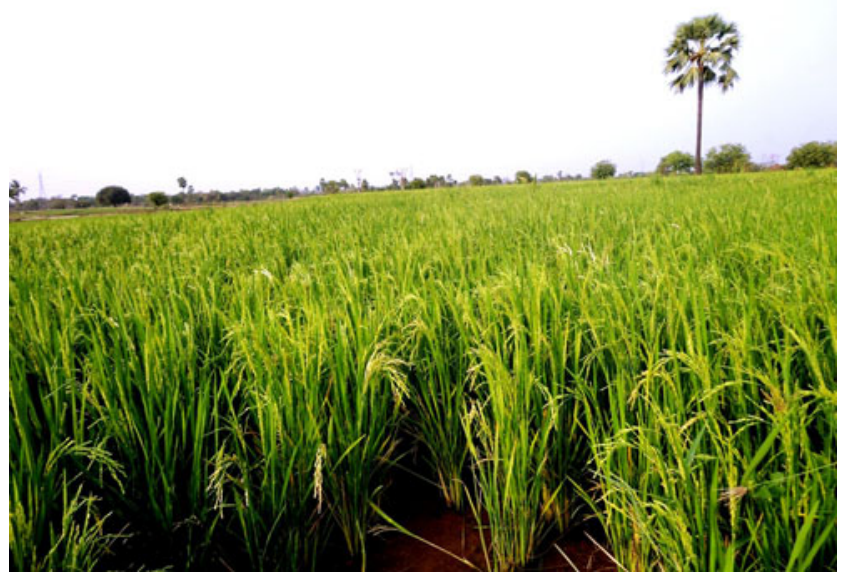

Fig. 6 Rice paddies are wetland agroecosytems facing threat of cadmium contamination. This has serious human health implications such as bone mineralization. Excessive use of rock phosphate fertilizer and irrigation with contaminated groundwater must be strictly monitored to ensure food safety. Sustainable agriculture practices (some of which are covered in this paper) minimize $\mathrm{Cd}$ translocation in rice fields in an eco-friendly manner

\section{Outlook}

Cadmium minimization must be an important demand during cultivation of rice especially in areas prone to industrial pollution (Fig. 6). Development of biosensors that indicate field $\mathrm{Cd}$ level is feasible to screen Cd-contaminated fields on a large scale. Selection of low-cost and widely applicable methods for Cd reduction in rice is preferred. Efficiency of field-based techniques such as application of soil amendments and phytoremediation needs further improvement through technological approach (Prasad 2004; Rajkumar et al. 2012). Establishment of database of amendments will be helpful for immediate remediation programs in contaminated fields. The scope of biofortification of rice with micronutrients that reduce $\mathrm{Cd}$ accumulation remains unexplored. Generation of rice mutants and the ability of these mutants in $\mathrm{Cd}$ uptake and $\mathrm{Cd}$ allocation into grains need to be studied through high-throughput methods (Uraguchi and Fujiwara 2012). Application of knowledge that comes with plant metal transporters must be explored for reducing Cd uptake especially that of silicon which is reported to be essential for the growth of rice (Ma et al. 2006; Vaculík et al. 2012). Transgenic rice having bacterial metal excluder is another promising area to be explored. Vast germplasm available in case of rice plants must be screened for hybridization strategies (Ishikawa et al. 2012). Silencing of Cd uptake genes using repressors is another approach to be studied along with its effect on essential nutrient uptake.
Acknowledgement Abin Sebastian gratefully acknowledges the award of Senior Research Fellowship by CSIR-UGC NET, New Delhi. M.N.V. Prasad is recipient of Pitamber Pant National Environment Fellowship, Ministry of Environment and Forests, Govt. of India.

\section{References}

Adamu CI, Nganje TN (2010) Heavy metal contamination of surface soil in relationship to land use patterns: a case study of Benue State, Nigeria. Mater Sci Appl 1:127-134. doi:10.4236/msa.2010.13021

Adriano DC, Wenzel WW, Vangronsveld J, Bolan NS (2004) Role of assisted natural remediation in environmental cleanup. Geoderma 122:121-142. doi:10.1016/j.geoderma.2004.01.003

Agrawal GK, Rakwal R, Yonekura M, Kubo A, Saji H (2002) Rapid induction of defense/stress-related proteins in leaves of rice (Oryza sativa) seedlings exposed to ozone is preceded by newly phosphorylated proteins and changes in a 66-kDA ERK-type MAPK. J Plant Physiol 159:361-369. doi:10.1078/0176-1617-00741

Antosiewicz DM, Henning J (2004) Overexpression of LTC1 in tobacco enhances the protective action of calcium against cadmium toxicity. Environ Pollut 129:237-245. doi:10.1016/j.envpol.2003.10.025

Appel C, Ma LQ, Rhue RD, Reve W (2008) Sequential sorption of lead and cadmium in three tropical soils. Environ Pollut 155:132140. doi:10.1016/j.envpol.2007.10.026

Arao T, Ae N (2003) Genotypic variations in cadmium levels of rice grain. Soil Sci Plant Nutr 287:223-233. doi:10.1080/ 00380768.2003.10410035

Arao T, Kawasaki A, Baba K, Mori S, Matsumoto S (2009) Effects of water management on cadmium and arsenic accumulation and dimethylarsinic acid concentrations in Japanese rice. Environ Sci Technol 43:9361-9367. doi:10.1021/es9022738

Arvind P, Prasad MNV (2005) Cadmium-zinc interactions in a hydroponic system using Ceratophyllum demersum L.: adaptive ecophysiology, biochemistry and molecular toxicology. Braz J Plant Physiol 17(1):3-20. doi:10.1590/S1677-04202005000100002

Aslan A, Çiçek A, Yazici K, Karagöz Y, Turan M, Akku F, Yildirim OS (2011) The assessment of lichens as bioindicator of heavy metal pollution from motor vehicles activities. Afr J Agric Res 6(7):1698-1706. doi:10.5897/AJAR10.331

Baize D (2008) Cadmium in soils and cereal grains after sewagesludge application on French soils. A review. Agron Sustain Dev 29:175-184. doi:10.1051/agro:2008031

Baize D, Bellanger L, Tomassone R (2009) Relationships between concentrations of trace metals in wheat grains and soil. Agron Sustain Dev 29:297-312. doi:10.1051/agro:2008057

Basta NT, McGowen SL (2004) Evaluation of chemical immobilization treatments for reducing heavy metal transport in a smeltercontaminated soil. Environ Pollut 127:73-82. doi:10.1016/ S0269-7491(03)00250-1

Battaglia A, Calace N, Nardi E, Petronio BM, Pietroletti M (2003) Paper mill sludge-soil mixture: kinetic and thermodynamic tests of cadmium and lead sorption capability. Microchem J 75:97102. doi:10.1016/S0026-265X(03)00074-2

Belimov AA, Hontzeas N, Safronova VI, Demchinskaya SV, Piluzza G, Bullitta S, Glick BR (2005) Cadmium-tolerant plant growthpromoting bacteria associated with the roots of Indian mustard (Brassica juncea L. Czern.). Soil Biol Biochem 37:241-250

Benavides MP, Gallego SM, Tomaro ML (2005) Cadmium toxicity in plants. Braz J Plant Physiol 17(1):21-34. doi:10.1590/S167704202005000100003 
Berg B (2000) Litter decomposition and organic matter turnover in northern forest soils. Forest Ecol Manag 133:13-22. doi:10.1016/ S0378-1127(99)00294-7

Boisson J, Mench M, Sappin-Didier V, Solda P, Vangronsveld J (1998) Short-term in situ immobilization of $\mathrm{Cd}$ and $\mathrm{Ni}$ by beringite and steel shots application to long-term sludged plots. Agron Sustain Dev 18(5-6):347-359. doi:10.1051/agro:19980502

Boisson J, Mench M, Vangronsveld J, Ruttens A, Kop-ponen P, De Koe T (1999) Immobilization of trace metals and arsenic by different soil additives: evaluation by means of chemical extractions. Commun Soil Sci Plant 30:365-387. doi:10.1080/00103629909370210

Bolan NS, Makino T, Kunhikrishnan A, Kim PJ, Ishikawa S, Murakami M, Naidu R, Kirkham MB (2013) Cadmium contamination and its risk management in rice ecosystems. Adv Agron 119:183-273. doi:10.1016/B978-0-12-407247-3.00004-4

Bolan NS, Adriano DC, Mani P, Duraisamy A, Arulmozhiselvan S (2003) Immobilization and phytoavailability of cadmium in variable charge soils: II. Effect of lime addition. Plant Soil 250:187198. doi:10.1023/A:1026288021059

Brams E, Anthony W (1983) Cadmium and lead through an agricultural food chain. Sci Total Environ 28:295-306. doi:10.1016/ S0048-9697(83)80027-8

Callahan DL, Baker AJM, Kolev SD, Wedd AG (2006) Metal ion ligands in hyper accumulating plants. J Biol Inorg Chem 11:212. doi:10.1007/s00775-005-0056-7

Casova K, Cerny J, Szakova J, Balik J, Tlustos P (2009) Cadmium balance in soils under different fertilization managements including sewage sludge application. Plant Soil Environ 55(8):353-361

Cataldo DA, Garland TR, Wildung RE (1983) Cadmium uptake kinetics in intact soybean plants. Plant Physiol 73:844-848. doi:10.1104/pp. 73.3.844

Cattani I, Romani M, Boccelli R (2008) Effect of cultivation practices on cadmium concentration in rice grain. Agron Sustain Dev 28:265-271. doi:10.1051/agro:2007033

Chaney RL, Malik M, Li YM, Brown SL, Brewer EP, Angle JS, Baker AJM (1997) Phytoremediation of soil metals. Curr Opin Biotech 8:279-284. doi:10.1016/S0958-1669(97)80004-3

Chaney RL, Reeves PG, Ryan JA, Simmons RW, Welch RM, Angle JS (2004) An improved understanding of soil Cd risk to humans and low cost methods to remediate soil $\mathrm{Cd}$ risks. Biometals 17(5):549-553. doi:10.1023/B:BIOM.0000045737.85738.cf

Chen HM, Zheng CR, Tu C, Shen ZG (2000) Chemical methods and phytoremediation of soil contaminated with heavy metals. Chemosphere 41:229-234. doi:10.1016/S0045-6535(99)00415-4

Cheng L, Wang F, Shou H, Huang F, Zheng L, He F, Li J, Fang-Jie Z, Ueno D, Ma JF, Wu P (2007) Mutation in nicotianamine aminotransferase stimulated the $\mathrm{Fe}(\mathrm{II})$ acquisition system and led to iron accumulation in rice. Plant Physiol 145:1647-1657. doi:10.1104/pp. 107.107912

Cherian S, Oliveira MM (2005) Transgenic plants in phytoremediation: recent advances and new possibilities. Environ Sci Technol 39:9377-9390. doi:10.1021/es0511341

Christensen TH (1984) Cadmium soil sorption at low concentrations: effect of time, cadmium load, $\mathrm{pH}$ and calcium. Water Air Soil Pollut 21:105-114. doi:10.1007/BF00163616

Chlopecka A, Adriano DC (1997) Influence of zeolite, apatite and Feoxide on $\mathrm{Cd}$ and $\mathrm{Pb}$ uptake by crops. Sci Total Environ 207:195206. doi:10.1016/S0048-9697(97)00268-4

Chlopecka A (1996) Forms of $\mathrm{Cd}, \mathrm{Cu}, \mathrm{Pb}$, and $\mathrm{Zn}$ in soil and their uptake by cereal crops when applied jointly as carbonates. Water Air Soil Pollut 87:297-309. doi:10.1007/BF00696843

Chou TS, Chao YY, Huang WD, Hong CY, Kao CH (2011) Effect of magnesium deficiency on antioxidant status and cadmium toxicity in rice seedlings. J Plant Physiol 168:1021-1030. doi:10.1016/ j.jplph.2010.12.004
Christofi N, Ivshina IB (2002) Microbial surfactants and their use in field studies of soil remediation. Appl Microbiol 93:915-929. doi:10.1046/j.1365-2672.2002.01774.x

Clemens S, Palmgren MG, Krämer U (2002) A long way ahead: understanding and engineering plant metal accumulation. Trends Plant Sci 7:302-315. doi:10.1016/S1360-1385(02)02295-1

Colangelo EP, Guerinot ML (2006) Put the metal to the petal: metal uptake and transport throughout plants. Curr Opin Plant Biol 9:322-330. doi:10.1016/j.pbi.2006.03.015

Çotuk Y, Belivermiș M, Kihc O (2010) Environmental biology and pathophysiology of cadmium. IUFS J Biol 69(1):1-5

Collard BCY, Mackill DJ (2008) Marker-assisted selection: an approach for precision plant breeding in the twenty-first century. Phil Trans R Soc B 363:557-572. doi:10.1098/ rstb.2007.2170

Coudert Y, Périn C, Courtois B, Khong NG, Ganet P (2010) Genetic control of root development in rice, the model cereal. Trends Plant Sci 15(4):219-226. doi:10.1016/j.tplants.2010.01.008

Curie C, Briat JF (2003) Iron transport and signaling in plants. Annu Rev Plant Biol 54:183-206. doi:10.1146/annurev.arplant. 54.031902 .135018

Deja J (2002) Immobilization of $\mathrm{Cr}^{6+}, \mathrm{Cd}^{2+}, \mathrm{Zn}^{2+}$ and $\mathrm{Pb}^{2+}$ in alkaliactivated slag binders. Cem Concr Res 32:1971-1979. doi:10.1016/S0008-8846(02)00904-3

del Castilho P, Chandron WJ, Salomons W (1993) Influence of cattle manure slurry application on the solubility of cadmium, copper, zinc in a manured acidic loamy sand soil. J Environ Qual 22:279-689

Dell'Amico E, Cavalca L, Andreoni V (2008) Improvement of Brassica napus growth under cadmium stress by cadmium resistant rhizobacteria. Soil Biol Biochem 40:74-84. doi:10.1016/ j.soilbio.2007.06.024

Dermont G, Bergeron M, Mercier G, Richer-Lafleche M (2008) Soil washing for metal removal: a review of physical/chemical technologies and field applications. J Hazard Mater 152:1-31. doi:10.1016/j.jhazmat.2007.10.043

Dong J, Mao WH, Zhang GP, Wu FB, Cai Y (2007) Root excretion and plant tolerance to cadmium toxicity - a review. Plant Soil Environ 53(5):193-200

Eriksson JE (1990) Effects of nitrogen-containing fertilizers on solubility and plant uptake of cadmium. Water Air Soil Pollut 49:355368. doi:10.1007/BF00507075

Fässler E, Plaza S, Pairraud PA, Gupta SK, Robinson B, Schulin R (2011) Expression of selected genes involved in cadmium detoxification in tobacco plants grown on a sulphur-amended metalcontaminated field. Environ Exp Bot 70:158-165. doi:10.1016/ j.envexpbot.2010.08.012

Fernández-Nava Y, Ulmanu M, Anger I, Marañón E, Castrillón L (2011) Use of granular bentonite in the removal of mercury (II), cadmium (II) and lead (II) from aqueous solutions. Water Air Soil Pollut 215:239-249. doi:10.1007/s11270-010-0474-1

Figueroa E (2008) Are more restrictive food cadmium standards justifiable health safety measures or opportunistic barriers to trade? An answer from economics and public health. Sci Total Environ 389:1-9. doi:10.1016/j.scitotenv.2007.08.015

Flick DF, Kraybill HF, Dlmitroff JM (1971) Toxic effects of cadmium: a review. Environ Res 4(2):71-85. doi:10.1016/0013-9351(71)90036-3

Fuloria A, Saraswat S, Rai JPN (2009) Effect of Pseudomonas fluorescens on metal phytoextraction from contaminated soil by Brassica juncea. Chem Ecol 25:385-396. doi:10.1080/ 02757540903325096

Gallardo A (2003) Spatial variability of soil properties in a floodplain forest in Northwest Spain. Ecosystems 6:564-576. doi:10.1007/ s10021-003-0198-9

Gallego SM, Pena LB, Barcia RA, Azpilicueta CE, Iannone MF, Rosales EP, Zawoznik MS, Groppa MD, Benavides MP (2012) Unravelling cadmium toxicity and tolerance in plants: insight into 
regulatory mechanisms. Environ Exp Bot 83:33-46. doi:10.1016/ j.envexpbot.2013.02.008

Garg RN, Das DK, Sharma AM, Mukherjee J, Singh G (2000) Soil physical properties and paddy yield as influenced by puddling methods. Ann Agr Res 21(2):192-198

Gill SS, Tuteja N (2011) Cadmium stress tolerance in crop plants - probing the role of sulfur. Plant Signal Behav 6(2):215222. doi:10.4161/psb.6.2.14880

Godt J, Scheidig F, Grosse-Siestrup C, Esche V, Brandenburg P, Reich A, Groneberg DA (2006) The toxicity of cadmium and resulting hazards for human health. J Occup Med Toxicol 1:22. doi:10.1186/1745-6673-1-22

Gong ZT (1983) Pedogenesis of paddy soil and its significance in soil classification. Soil Sci 135:5-10

Grant CA, Clarke JM, Duguide S, Chaneyd RL (2008) Selection and breeding of plant cultivars to minimize cadmium accumulation. Sci Total Environ 390:301-331. doi:10.1016/ j.scitotenv.2007.10.038

Gou X, Li J (2012) Activation tagging. Methods Mol Biol 876:117133. doi:10.1007/978-1-61779-809-2 9

Hagemeyer J, Kahle H, Breckle SW, Waisel Y (1986) Cadmium in Fagus sylvatica $\mathrm{L}$. trees and seedlings: leaching, uptake and interconnection with transpiration. Water Air Soil Pollut 29(4):347-359. doi:10.1007/BF00283442

Hall J (2002) Cellular mechanism of heavy metal detoxification and tolerance. J Exp Bot 53(366):1-11. doi:10.1093/jexbot/53.366.1

Hall JL, Williams LE (2003) Transition metal transporters in plants. J Exp Bot 54(393):2601-2613. doi:10.1093/jxb/erg303

Hamon RE, Mj ML, Naidu R, Correll R (1998) Long-term changes in cadmium bioavailability in soil. Environ Sci Technol 32(23):3699-3703. doi:10.1021/es980198b

Han CA, Tlusto SP, Száková J, Habart J, Gondek K (2008) Direct and subsequent effect of compost and poultry manure on the bioavailability of cadmium and copper and their uptake by oat biomass. Plant Soil Environ 54(7):271-278

Han FX, Kingery WL, Selim HM (2001) Accumulation, redistribution and bioavailability of heavy metals in waste-amended soils. In: Iskandar IK, Kirkham MB (eds) Trace elements in soils: bioavailability, flux and transfer. Lewis, Washington, DC, pp 145-174

Haouari CC, Nasraoui AH, Bouthour D, Houda MD, Daieb CB, Mnai J, Gouia H (2012) Response of tomato (Solanum lycopersicon) to cadmium toxicity: growth, element uptake, chlorophyll content and photosynthesis rate. Afr J Plant Sci 6(1):1-7. doi:10.5897/ AJPS11.107

Harada E, Choi Y-E, Tsuchisaka A, Obata H, Sano H (2001) Transgenic tobacco plants expressing a rice cysteine synthase gene are tolerant to toxic levels of cadmium. J Plant Physiol 158:655-661. doi:10.1078/0176-1617-00314

Hasan SA, Fariduddin Q, Ali B, Hayat S, Ahmad A (2009) Cadmium: toxicity and tolerance in plants. Environ Biol 30(2):165-174

Hart JJ, Welch RM, Norvell WA, Sullivan LA, Kochian LV (1998) Characterization of cadmium binding, uptake, translocation in intact seedlings of bread and durum wheat cultivars. Plant Physiol 116:1413-1420. doi:10.1104/pp. 118.1.219

Hsieh HM, Liu WK, Huang PC (1995) A novel stress-inducible metallothionein-like gene from rice. Plant Mol Biol 28:381-389. doi:10.1007/BF00020388

Haydon MJ, Cobbett CS (2007) Transporters of ligands for essential metal ions in plants. New Phytol 174:499-506. doi:10.1111/ j.1469-8137.2007.02051.x

Huang JW, Chen J, Berti WR, Cunningham SD (1997) Phytoremediation of lead-contaminated soils: role of synthetic chelates in lead phytoextraction. Environ Sci Technol 31(3):800-805. doi:10.1021/ es9604828

Hutton M, Chaney RL, Krishnamurti CR, Olade MA, Page AL (1987) Group report: cadmium. In: Hutchinson TC, Meema KM (eds)
Lead, mercury, cadmium and arsenic in the environment. Wiley, New York, pp 35-41

Ishikawa S, Ishimaru Y, Igura M, Kuramata M, Abe T, Senoura T, Hase Y, Arao T, Nishizawa NK, Nakanishi H (2012) Ion-beam irradiation, gene identification, and marker-assisted breeding in the development of low-cadmium rice. PNAS. doi:10.1073/ pnas. 1211132109

Ishikawa S, Abe T, Kuramata M, Yamaguchi MOT, Yamamoto T, Yano M (2010) Major quantitative trait locus for increasing cadmium specific concentration in rice grain is located on the short arm of chromosome 7. J Exp Bot 61(3):923-934. doi:10.1093/jxb/ erp360

Ishikawa S, Suzui N, Ito-Tanabata S, Ishii S, Igura M, Abe T, Kuramata M, Kawachi N, Fujimaki S (2011) Real-time imaging and analysis of differences in cadmium dynamics in rice cultivars (Oryza sativa) using positron-emitting $107 \mathrm{Cd}$ tracer. BMC Plant Biol 11:172. doi:10.1186/1471-2229-11-172

Ishimaru Y, Takahashi R, Bashir K, Shimo H, Senoura T, Sugimoto K, Ono K, Yano M, Ishikawa S, Arao T, Nakanishi H, Nishizawa NK (2012) Characterizing the role of rice NRAMP5 in manganese, iron and cadmium transport. Sci Rep 2:286. doi:10.1038/ srep00286

Ishimaru Y, Kakei Y, Shimo H, Bashir K, Sato Y, Sato Y, Uozumi N, Nakanishi H, Nishizawa NK (2011) A rice phenolic efflux transporter is essential for solubilizing precipitated apoplasmic iron in the plant stele. J Biol Chem 286(28):24649-24655. doi:10.1074/ jbc.M111.221168

Jabeen R, Ahmad A, Iqbal M (2009) Phytoremediation of heavy metals: physiological and molecular mechanisms. Bot Rev 75:339-364. doi:10.1007/s12229-009-9036-x

Jadia CD, Fulekar MH (2008) Phytoremediation: the application of vermicompost to remove zinc, cadmium, copper, nickel and lead by sunflower plant. Environ Eng Manag J 7(5):547-558

Jayaram K, Prasad MNV (2009) Removal of Pb (II) from aqueous solution by seed powder of Prosopis juliflora DC. J Hazard Mater 169:991-997. doi:10.1016/j.jhazmat.2009.04.048

Jezeque K, Lebeau T (2008) Soil bioaugmentation by free and immobilized bacteria to reduce potentially phytoavailable cadmium. Bioresour Technol 99:690-698. doi:10.1016/j.biortech.2007.02.002

Jiao Y, Grant CA, Bailey LD (2004) Effects of phosphorus and zinc fertilizer on cadmium uptake and distribution in flax and durum wheat. J Sci Food Agric 84(8):777-785. doi:10.1002/jsfa.1648

Johns T, Eyzaguirre PB (2007) Biofortification, biodiversity and diet: a search for complementary applications against poverty and malnutrition. Food Policy 32:1-24. doi:10.1016/j.foodpol.2006.03.014

Joschim HJ, Makoi R, Ndakidemi PA (2009) The agronomic potential of vesicular-arbuscular mycorrhiza (AM) in cereals-legume mixtures in Africa. Afr J Microbiol Res 3(11):664-675

Jung MC (2008) Heavy metal concentrations in soils and factors affecting metal uptake by plants in the vicinity of a Korean $\mathrm{Cu}-$ W mine. Sensors 8:2413-2423

Kato M, Ishikawa S, Inagaki $\mathrm{K}$, Chiba $\mathrm{K}$, Hayashi $\mathrm{H}$, Yanagisawa $\mathrm{S}$, Yoneyama T (2010) Possible chemical forms of cadmium and varietal differences in cadmium concentrations in the phloem sap of rice plants (Oryza sativa L.). Soil Sci Plant Nutr 56:839-847. doi:10.1111/j.1747-0765.2010.00514.x

Karapinar N, Donat R (2009) Adsorption behaviour of $\mathrm{Cu}^{2+}$ and $\mathrm{Cd}^{2+}$ onto natural bentonite. Desalination 249:123-129. doi:10.1016/ j.desal.2008.12.046

Karkhanis M, Jadia CD, Fulekar MH (2005) Rhizofilteration of metals from coal ash leachate. Asian J Water Environ Pollut 3(1):91-94

Keller C, Marchetti M, Rossi L, Lugon-Moulin N (2005) Reduction of cadmium availability to tobacco (Nicotiana tabacum) plants using soil amendments in low cadmium-contaminated agricultural soils: a pot experiment. Plant Soil 276:69-84. doi:10.1007/s11104-0053101-y 
Khan AG, Kuek C, Chaudhry TM, Khoo CS, Hayes WJ (2000) Role of plants, mycorrhizae and phytochelators in heavy metal contaminated land remediation. Chemosphere 41:197-207. doi:10.1016/ S0045-6535(99)00412-9

Kim DY, Bovet L, Maeshima M, Martinoia E, Lee Y (2007) The ABC transporter AtPDR8 is a cadmium extrusion pump conferring heavy metal resistance. Plant J 50:207-218. doi:10.1111/j.1365313X.2007.03044.X

Kirkham MB (2006) Cadmium in plants on polluted soils: effects of soil factors, hyperaccumulation, amendments. Geoderma 137:1932. doi:10.1016/j.geoderma.2006.08.024

Knox AS, Seaman JC, Mench MJ, Vangronsveld J (2001) Remediation of metal- and radionuclides-contaminated soils by in situ stabilization techniques. In: Iskandar IK (ed) Environmental restoration of metals contaminated soils. CRC, Boca Raton, pp 21-60

Kobayashi J (1978) Pollution by cadmium and the itai-itai disease in Japan. In: Oeheme FW (ed) Toxicity of heavy metals in the environment. Marcel Dekker, New York, pp 199-260

Kögel-Knabner I, Amelung W, Cao Z, Fiedler S, Frenzel P, Jahn R, Kalbitz K, Kölbl A, Schloter M (2010) Biogeochemistry of paddy soils. Geoderma 157(1-2):1-14. doi:10.1016/j.geoderma.2010.03.009

Kramer U (2010) Metal hyperaccumulation in plants. Annu Rev Plant Biol 61:517-534. doi:10.3923/jest.2011.118.138

Kuramata M, Masuya S, Takahashi Y, Kitagawa E, Inoue C, Ishikawa S, Youssefian S, Kusano T (2009) Novel cysteine-rich peptides from Digitaria ciliaris and Oryza sativa enhance tolerance to cadmium by limiting its cellular accumulation. Plant Cell Physiol 50(1):106-117. doi:10.1093/pcp/pcn175

Lagerwerff JV, Specht AW (1970) Contamination of roadside soil and vegetation with cadmium nickel, lead and zinc. Environ Sci Technol 4:583-586. doi:10.1021/es60042a001

Lalhruaitluanga H, Jayaram K, Prasad MNV, Kumar KK (2010) Lead(II) adsorption from aqueous solutions by raw and activated charcoals of Melocanna baccifera Roxburgh (bamboo) - a comparative study. J Hazard Mater 175(1-3):311-318. doi:10.1016/ j.jhazmat.2009.10.005

Lee MH, Choi SY, Moon H (1993) Complexation of cadmium (II) with soil fulvic acid. Bull Korean Chem Soc 14(4):453-457. doi:10.1139/v79-206

Lee S, An G (2009) Over-expression of OsIRT1 leads to increased iron and zinc accumulations in rice. Plant Cell Environ 32:408-416. doi:10.1111/j.1365-3040.2009.01935.x

Lee S, Kim YY, Lee Y, An G (2007) Rice P1B-type heavy-metal ATPase, OsHMA9, is a metal efflux protein. Plant Physiol 145(3):831-842. doi:10.1104/pp. 107.102236

Levi-Minzi R, Petruzzelli G (1984) The influence of phosphate fertilizers on Cd solubility in soil. Water Air Soil Pollut 23:423-429. doi:10.1007/BF00284737

Lin SH, Juang RS (2002) Heavy metal removal from water by sorption using surfactant-modified montmorillonite. J Hazard Mater 92 (3):315-326. doi:10.1016/S0304-3894(02)00026-2

Lish D (2002) Mutator transposons. Trends Plant Sci 7(11):498-504. doi:10.1016/S1360-1385(02)02347-6

Liu W, Zhou Q, An J, Sun Y, Liu R (2010) Variations in cadmium accumulation among Chinese cabbage cultivars and screening for Cd-safe cultivars. J Hazard Mater 173:737-743. doi:10.1016/ j.jhazmat.2009.08.147

Livera JD, Beak D, Kirby J, Hettiarachchi G, McLaughlin M (2011) Cadmium solubility in paddy soils: effects of soil oxidation, metal sulfides and competitive ions. Sci Total Environ 409(8):14891497. doi:org/10.1016/j.scitotenv.2010.12.028

Llamas A, Ullrich CI, Sanz A (2000) $\mathrm{Cd}^{2+}$ effects on transmembrane electrical potential difference, respiration and membrane permeability of rice (Oryza sativa L) roots. Plant Soil 219:21-28. doi:10.1023/A:1004753521646
López-Chuken UJ, Young SD, Sánchez-González MN (2010) The use of chloro-complexation to enhance cadmium uptake by Zea mays and Brassica juncea: testing a "free ion activity model" and implications for phytoremediation. Int J Phytoremediation 12(7):680-696. doi:10.1080/15226510903353161

Lovley DR, Coates JD (1997) Bioremediation of metal contamination. Curr Opin Biotechnol 8(3):285-289. doi:10.1016/S09581669(97)80005-5

Lugon-Moulin N, Ryan L, Donini P, Rossi L (2006) Cadmium content of phosphate fertilizers used for tobacco production. Agron Sustain Dev 26:151-155. doi:10.1051/agro:2006010

Lui H, Zhang J, Christie P, Zhang F (2008) Influence of iron plaque on uptake and accumulation of Cd by rice (Oryza sativa L.) seedling grown in soil. Sci Total Environ 394:361-368. doi:10.1016/ j.scitotenv.2008.02.004

Lux A, Martink M, Vaculık M, White PJ (2011) Root responses to cadmium in the rhizosphere: a review. J Exp Bot 62(1):21-37. doi:10.1093/jxb/erq281

Ma JF, Tamai K, Yamaji N, Mitani N, Konishi S, Katsuhara M, Ishiguro M, Murata Y, Yano M (2006) A silicon transporter in rice. Nature 440:688-691. doi:10.1038/nature04590

Ma LQ, Komar KM, Tu C, Zhang W, Cai Y, Kennelley ED (2001) A fern that hyperaccumulates arsenic. Nature 409:579-579. doi: $10.1038 / 35054664$

Ma W, Tobin JM (2003) Development of multimetal binding model and application to binary metal biosorption onto peat biomass. Water Res 37:3967-3977. doi:10.1016/S0043-1354(03)00290-2

Macaskie LE, Dean ACR, Cheetham AK, Jakeman RJB, Skarnulis AJ (1987) Cadmium accumulation by a Citvobacter sp.: the chemical nature of the accumulated metal precipitate and its location on the bacterial cells. J Gen Microbiol 133:539-544. doi:10.1099/ 00221287-133-3-539

Madejón E, de Mora AP, Felipe E, Burgos P, Cabrera F (2006) Soil amendments reduce trace element solubility in a contaminated soil and allow regrowth of natural vegetation. Environ Pollut 139(1):40-52. doi:10.1016/j.envpol.2005.04.034

Magneschi L, Perata P (2009) Rice germination and seedling growth in the absence of oxygen. Ann Bot 103:181-196. doi:10.1093/aob/ men 121

Mahler RJ, Bingham FT, Page AL (1978) Cadmium-enriched sewage sludge application to acid and calcareous soils - effect on yield and cadmium uptake by lettuce and chard. J Environ Qual 7:274-281

Masuda H, Ishimaru Y, Aung MS, Kobayashi T, Kakei Y, Takahashi M, Higuchi K, Nakanishi H, Nishizawa NK (2012) Iron biofortification in rice by the introduction of multiple genes involved in iron nutrition. Sci Rep 2:543. doi:10.1038/srep00543

Mathialagan T, Viraraghavan T (2002) Adsorption of cadmium from aqueous solutions by perlite. J Hazard Mat 94:291-303. doi:10.1016/S0304-3894(02)00084-5

Matsi TH, Hatzigiannakis EG, Arampatzis GK, Panoras AG (2007) Available Cd content of salt-affected and normal soils of Halastra-Kalohori area. Global Nest J 9(3):195-200

Matsuda T, Kuramata M, Takahashi Y, Kitagawa E, Youssefian S, Kusano T (2009) A novel plant cysteine-rich peptide family conferring cadmium tolerance to yeast and plants. Plant Signal Behav 5:419-421. doi:10.1093/pcp/pcn175

McLaughlin MJ, Maier NA, Freeman K, Tiller KG, Williams CMJ, Smart MK (1995) Effect of potassic and phosphatic fertilizer type, fertilizer $\mathrm{Cd}$ concentration and zinc rate on cadmium uptake by potatoes. Fert Res 40:63-70. doi:10.1007/BF00749863

McDonald AJ, Riha SJ, Duxbury JM, Steenhuis TS, Lauren JG (2006) Soil physical responses to novel rice cultural practices in the rice-wheat system: comparative evidence from a swelling soil in Nepal. Soil Till Res 86:163-175. doi:10.1016/ j.still.2005.02.005 
Mediouni C, Benzarti O, Tray B, Ghorbel MH, Jemal F (2006) Cadmium and copper toxicity for tomato seedlings. Agron Sustain Dev 26:227-232. doi:10.1051/agro:2006008

Mendoza-Cózatl D, Loza-Tavera H, Hernández-Navarro A, MorenoSánchez R (2003) Sulfur assimilation and glutathione metabolism under cadmium stress in yeast, protists and plants. FEMS Microbiol Rev 29(4):653-671. doi:10.1016/j.femsre.2004.09.004

Milner MJ, Kochian LV (2008) Investigating heavy-metal hyperaccumulation using Thlaspi caerulescens as a model system. Ann Bot 102:3-13. doi:10.1093/aob/mcn063

Miyadate H, Adachi S, Hiraizumi A, Tezuka K, Nakazawa N, Kawamoto T, Katou K, Kodama I, Sakurai K, Takahashi H, Satoh-Nagasawa N, Watanabe A, Fujimura T, Akagi H (2011) OsHMA3, a P1B-type of ATPase affects root-to-shoot cadmium translocation in rice by mediating efflux into vacuoles. New Phytol 189(1):190-199. doi:10.1111/j.1469-8137.2010.03459.x

Moons A (2003) Ospdr9, which encodes a PDR-type ABC transporter, is induced by heavy metals, hypoxic stress and redox perturbations in rice roots. FEBS Lett 553:370-376. doi:10.1016/S00145793(03)01060-3

Moreno JL, Hernández T, Garcia C (1999) Effects of a cadmiumcontaminated sewage sludge compost on dynamics of organic matter and microbial activity in an arid soil. Biol Fert Soils 28(3):230-237. doi:10.1007/s003740050487

Mukhopadhyay A, Vij S, Tyagi AK (2004) Overexpression of a zincfinger protein gene from rice confers tolerance to cold, dehydration, and salt stress in transgenic tobacco. PNAS 101(16):63096314. doi:10.1073pnas.0401572101

Nakanishi H, Ogawa H, Ishimaru Y, Mori S, Nishizawa NK (2006) Iron deficiency enhances cadmium uptake and translocation mediated by the $\mathrm{Fe}^{2+}$ transporters OsIRT1 and OsIRT2 in rice. Soil Sci Plant Nutr 52:464-469. doi:10.1111/j.1747-0765.2006.00055.x

Nazar R, Iqbal N, Masood A, Khan MIR, Syeed S, Khan NA (2012) Cadmium toxicity in plants and role of mineral nutrients in its alleviation. AJPS 3:1476-1489. doi:10.4236/ajps.2012.310178

Nocito FF, Lancilli C, Dendena B, Lucchini G, Sacchi GA (2011) Cadmium retention in rice roots is influenced by cadmium availability, chelation and translocation. Plant Cell Environ 34:9941008. doi:10.1111/j.1365-3040.2011.02299.x

Nriagu JO, Pacyna JM (1998) Quantitative assessment of world-wide contamination of air, water and soils by trace metals. Nature 333:134-139. doi:10.1038/333134a0

Oda K, Otani M, Uraguchi S, Akihiro T, Fujiwara T (2011) Rice ABCG43 is Cd inducible and confers Cd tolerance on yeast. Biosci Biotechnol Biochem 75(6):1211-1213. doi:10.1271/ bbb. 110193

Ok YS, Kim SC, Kim DK, Skousen JG, Lee JS, Cheong YW, Kim SJ, Yang JE (2011) Ameliorants to immobilize Cd in rice paddy soils contaminated by abandoned metal mines in Korea. Environ Geochem Health 33:23-30. doi:10.1007/s10653-010-9364-0

Oyewole OA (2012) Microbial communities and their activities in paddy fields: a review. J Vet Adv 2(2):74-80

Palmgren MG, Clemens S, Williams LE, Kramer U, Borg S, Schjørring JK, Sanders D (2008) Zinc biofortification of cereals: problems and solutions. Trends Plant Sci 13(9):1360-1385. doi:10.1016/ j.tplants.2008.06.005

Papoyan A, Kochian LV (2004) Identification of Thlaspi caerulescens genes that may be involved in heavy metal hyperaccumulation and tolerance. Characterization of a novel heavy metal transporting ATPase. Plant Physiol 136(3):3814-3823. doi:10.1104/pp. 104

Pereira MG, Arruda MAZ (2003) Vermicompost as a natural adsorbent material: characterization and potentialities for cadmium adsorption. J Braz Chem Soc 14(1):39-47. doi:10.1590/S0103-50532003000100007
Pierzynski GM, Schwab AP (1993) Bioavailability of zinc, cadmium and lead in a metal-contaminated alluvial soil. J Environ Qual 22:247-254

Pilon-Smits EAH (2005) Phytoremediation. Annu Rev Plant Biol 56: 15-39. doi:10.1146/annurev.arplant.56.032604.144214

Pitzschke A, Hirt H (2006) Mitogen-activated protein kinases and reactive oxygen species signaling in plants. Plant Physiol 141(2):351-356. doi:10.1104/pp. 106.079160

Poulsen L, Dudas MJ (1998) Attenuation of cadmium, fluoride and uranium in phosphogypsum process water by calcareous soil. Can J Soil Sci 78:351-357. doi:10.4141/S97-004

Prasad MNV (1995) Cadmium toxicity and tolerance in vascular plants. Environ Exp Bot 35(4):525-545. doi:10.1016/00988472(95)00024-0

Prasad MNV (2004) Phytoremediation of metals in the environment for sustainable development. Proc Indian Natl Sci Acad 70(1):71-98

Prasad MNV, Freitas H (1999) Feasible biotechnological and bioremediation: strategies for serpentine soils and mine spoils. EJB 2(1):36-50. doi:10.2225/vol2-issue1-fulltext-5

Prasad MNV, Freitas H (2002) Metal hyperaccumulation in plants - biodiversity prospecting for phytoremediation technology. EJB 6(3):285-321. doi:10.2225/vol6-issue3-fulltext-6

Prasad MNV (2008) Biofortification: nutritional security and relevance to human health. In: Prasad MNV (ed) Trace elements as contaminants and nutrients: consequences in ecosystems and human health. Wiley, New York, pp 161-182

Prasad MNV, Freitas H, Fraenzle S, Wuenschmann S, Markert B (2010) Knowledge explosion in phytotechnologies for environmental solutions. Environ Pollut 158(1):18-23. doi:10.1016/ j.envpol.2009.07.038

Prasad MNV, Nirupa N (2007) Phytoferritins - implications for human health and nutrition. Asian Australas J Plant Sci Biotechnol 1(1):1-9

Rajkumar M, Ae N, Prasad MNV, Freitas H (2010) Potential of siderophore-producing bacteria for improving heavy metal phytoextraction. Trends Biotechnol 28(3):142-149. doi:10.1016/ j.tibtech.2009.12.002

Rajkumar M, Sandhya S, Prasad MNV, Freitas H (2012) Perspectives of plant-associated microbes in heavy metal phytoremediation. Biotechnol Adv 30(6):1562-1574. doi:10.1016/ j.biotechadv.2012.04.011

Ramesh SA, Shin R, Eide DJ, Schachtman DP (2003) Differential metal selectivity and gene expression of two zinc transporters from rice. Plant Physiol 133:126-134. doi:10.1104/pp. 103

Rani A, Souche YS, Goel R (2009) Comparative assessment of in situ bioremediation potential of cadmium resistant acidophilic Pseudomonas putida 62BN and alkalophilic Pseudomonas monteilli 97AN strains on soybean. Int Biodeter Biodegr 63:6266. doi:10.1016/j.ibiod.2008.07.002

Rao TP, Yano K, Iijima M, Yamauchi A (2002) Regulation of rhizosphere acidification by photosynthetic activity in cowpea (Vigna unguiculata L. Walp.) seedlings. Ann Bot 89(2):213-220. doi:10.1093/aob/mcf030

Rate AW, Lee KM, French PA (2004) Application of biosolids in mineral sands mine rehabilitation: use of stockpiled topsoil decreases trace element uptake by plants. Bioresour Technol 91:223-231. doi:10.1016/S0960-8524(03)00206-2

Rauser WE (1999) Structure and function of metal chelators produced by plants: the case for organic acids, amino acids, phytin, and metallothioneins. Cell Biochem Biophys 31:19-48. doi:10.1007/ BF02738153

Reddy AR, Chaitanya KV, Vivekanandan M (2004) Drought-induced responses of photosynthesis and antioxidant metabolism in higher plants. J Plant Physiol 161(11):1189-1202. doi:10.1016/ j.jplph.2004.01.013 
Reniger P (1977) Concentration of cadmium in aquatic plants and algal mass in flooded rice culture. Environ Pollut 14:297-302. doi:10.1016/0013-9327(77)90141-0

Robinson B, Russell C, Hedley M, Clothier B (2001) Cadmium adsorption by rhizobacteria: implications for New Zealand pastureland. Agric Ecosyst Environ 87:315-321. doi:10.1016/S0167-8809(01)00146-3

Romheld V (1991) The role of phytosiderophores in acquisition of iron and other micronutrients in graminaceous species: an ecological approach. Plant Soil 130:127-134. doi:10.1007/BF00011867

Root RA, Miller RJ, Koeppe DE (1973) Uptake of cadmium - its toxicity, effect on the iron ratio in hydroponically grown corn. JEQ 4(4):473-476. doi:10.2134/jeq1975.00472425000400040011x

Sandalio LM, Dalruzo HC, Gomez M, Romero-Puetras MC, Del Rio LA (2001) Cadmium-induced changes in the growth and oxidative metabolism of pea plants. J Exp Bot 52(364):2115-2126. doi:10.1093/jexbot/52.364.2115

Saraswat S, Rai JPN (2011) Complexation and detoxification of Zn and $\mathrm{Cd}$ in metal accumulating plants. Rev Environ Sci Biotechnol 10(4):327-339. doi:10.1007/s11157-011-9250-y

Sarin C, Sarin S (2010) Removal of cadmium and zinc from soil using immobilized cell of biosurfactant producing bacteria. Environment Asia 3(2):49-53

Sarwar N, Saifullah MSS, Zia MH, Naeem A, Bibi S, Farid G (2010) Role of mineral nutrition in minimizing cadmium accumulation by plants. J Sci Food Agric 90:925-937. doi:10.1002/jsfa.3916

Sasaki A, Yamaji N, Yokosho K, Ma JF (2012) Nramp5 is a major transporter responsible for manganese and cadmium uptake in rice. Plant Cell 24(5):2155-2167. doi:10.1105/tpc.112.096925

Satarug S, Baker JR, Urbenjapol S, Haswell-Elkins Reilly PEB, Williams DJ, Moore MR (2003) A global perspective on cadmium pollution and toxicity in non-occupationally exposed population. Toxicol Lett 137:65-83. doi:org/10.1016/S0378-4274(02)00381-8

Satoh-Nagasawa N, Mori M, Nakazawa N, Kawamoto T, Nagato Y, Sakurai K, Takahashi H, Watanabe A, Akagi H (2012) Mutations in rice (Oryza sativa) heavy metal ATPase 2 (OsHMA2) restrict the translocation of zinc and cadmium. Plant Cell Physiol 53(1):213-224. doi:10.1093/pcp/pcr166

Sauve S, Hendershot W, Allen HE (2000) Solid-solution partitioning of metals in contaminated soils: dependence on $\mathrm{pH}$, total metal burden, organic matter. Environ Sci Technol 34:1125-1131. doi:10.1021/es9907764

Sauvé S, Manna S, Turmel MC, Roy AG, Courchesne F (2003) Solidsolution partitioning of $\mathrm{Cd}, \mathrm{Cu}, \mathrm{Ni}, \mathrm{Pb}, \mathrm{Zn}$ in the organic horizons of a forest soil. Environ Sci Technol 37:5191-5196. doi:10.1021/ es030059g

Schmidt U (2003) Enhancing phytoremediation: the effect of chemical soil manipulation on mobility, plant accumulation, and leaching of heavy metals. J Environ Qual 32:1939-1954. doi:10.2134/ jeq2003.1939

Schoeters G, Hond ED, Zuurbier M, Naginiene R, Hazel PVD, Stilianakis N, Ronchetti R, Koppe JG (2006) Cadmium and children: exposure and health effects. Acta Paediatr Suppl 453:50-54. doi:10.1080/08035320600886232

Sebastian A, Prasad MNV (2013) Cadmium accumulation retard activity of functional components of photo assimilation and growth of rice cultivars amended with vermicompost. Int J Phytoremediation 15:965-978. doi:10.1080/15226514.2012.751352

Shah K, Kumar RG, Verma S, Dubey RS (2001) Effect of cadmium on lipid peroxidation, superoxide anion generation and activities of antioxidant enzymes in growing rice seedlings. Plant Sci 161:1135-1144. doi:10.1016/S0168-9452(01)00517-9

Shah K, Nongkynrih JM (2007) Metal hyperaccumulation and bioremediation. Biol Plant 51:618-634. doi:10.1007/s10535-007-0134-5

Shah K (2011) Cadmium metal detoxification and hyperaccumulators. In: Sherameti I, Varma A (eds) Detoxification of heavy metals, Soil Biology 30. Springer, Berlin, pp 181-230
Shim D, Jae-Ung H, Lee J, Lee S, Choi Y, An G, Martinoia E, Lee Y (2009) Orthologs of the class A4 heat shock transcription factor HsfA4a confer cadmium tolerance in wheat and rice. Plant Cell 21(12):4031-4043. doi:10.1105/tpc.109.066902

Shimo H, Ishimaru Y, An G, Yamakawa T, Nakanishi H, Nishizawa NK (2011) Low cadmium (LCD), a novel gene related to cadmium tolerance and accumulation in rice. J Exp Bot 62(15):57275234. doi:10.1093/jxb/err300

Shirvani M, Shariatmadari H, Kalbasi M (2007) Kinetics of cadmium desorption from fibrous silicate clay minerals: influence of organic ligands and aging. Appl Clay Sci 37:175-184. doi:10.1016/ j.clay.2006.12.010

Silver S (1996) Bacterial resistances to toxic metal ions-a review. Gene 179:9-19. doi:10.1016/S0378-1119(96)00323-X

Singh BR, Myhr K (1998) Cadmium uptake by barley as affected by Cd sources and $\mathrm{pH}$ levels. Geoderma 84:185-194. doi:10.1016/ S0016-7061(97)00128-6

Sloan JJ, Basta NT (1995) Remediation of acid soils by using alkaline biosolids. JEQ 24:1097-1103

Smolders E, McLaughlin MJ (1996) Chloride increases cadmium uptake in Swiss chard in a resin-buffered nutrient solution. Soil Sci Soc Am J 60:1443-1447

So HB, Ringrose-Voase AJ (2000) Management of clay soils for rainfed lowland rice-based cropping systems: an overview. Soil Till Res 56:3-14. doi:10.1016/S0167-1987(00)00119-7

Street JJ, Sabey BR, Lindsay WL (1978) Influence of pH, phosphorus, cadmium, sewage sludge, incubation time on the solubility and plant uptake of cadmium. JEQ 7(2):286-290

Su-Hsia L, Reuy-Shin J (2002) Heavy metal removal from water by sorption using surfactant-modified montmorillonite. J Hazard Mater 92:315-326. doi:10.1016/S0304-3894(02)00026-2

Sundaramoorthy P, Chidambaram A, Ganesh KS, Unnikannan P, Baskaran L (2010) Chromium stress in paddy: (i) nutrient status of paddy under chromium stress; (ii) phytoremediation of chromium by aquatic and terrestrial weeds. C R Biol 333:597-607. doi:10.1016/j.crvi.2010.03.002

Takahashi R, Bashir K, Ishimaru Y, Nishizawa NK, Nakanishi H (2012a) The role of heavy-metal ATPases, HMAs, in zinc and cadmium transport in rice. Plant Signal Behav 7(12):1605-1607. doi:10.4161/psb.22454

Takahashi R, Ishimaru Y, Shimo H, Ogo Y, Senoura T, Nishizawa NK, Nakanishi H (2012b) The OsHMA2 transporter is involved in rootto-shoot translocation of $\mathrm{Zn}$ and $\mathrm{Cd}$ in rice. Plant Cell Environ 35(11):1948-1957. doi:10.1111/j.1365-3040.2012.02527.x

Takahashi R, Ishimaru Y, Senoura T, Shimo H, Ishikawa S, Arao T, Nakanishi H, Nishizawa NK (2011) The OsNRAMP1 iron transporter is involved in $\mathrm{Cd}$ accumulation in rice. $\mathrm{J}$ Exp Bot 62(14):4843-4850. doi:10.1093/jxb/err136

Tanaka A, Shikazono N, Hase Y (2010) Studies on biological effects of ion beams on lethality, molecular nature of mutation, mutation rate, and spectrum of mutation phenotype for mutation breeding in higher plants. Radiat Res 51:223-233. doi:10.1269/ jrr.09143

Tang S, Xi L, Zheng J, Li H (2003) Response to elevated $\mathrm{CO}_{2}$ of Indian mustard and sunflower growing on copper contaminated soil. Bull Environ Contam Toxicol 71:988-997

Tezuka K, Miyadate H, Katou K, Kodama I, Matsumoto S, Kawamoto T, Masaki S, Satoh H, Yamaguchi M, Sakurai K, Takahashi H, Satoh-Nagasawa N, Watanabe A, Fujimura T, Akagi H (2010) A single recessive gene controls cadmium translocation in the cadmium hyperaccumulating rice cultivar Cho-Ko-Koku. Theor Appl Genet 120:1175-1182. doi:10.1007/s00122-009-1244-6

Tóth T, Zsiros O, Kis M, Garab G, Kovács L (2012) Cadmium exerts its toxic effects on photosynthesis via a cascade mechanism in the cyanobacterium, Synechocystis PCC 6803. Plant Cell Environ 35(12):2075-2086. doi:10.1111/j.1365-3040.2012.02537.x 
Ueno D, Koyama E, Kono IOT, Yano M, Ma JF (2009) Identification of a novel major quantitative trait locus controlling distribution of $\mathrm{Cd}$ between roots and shoots in rice. Plant Cell Physiol 50(12):2223-2233. doi:10.1093/pcp/pcp160

Ueno D, Yamaji N, Kono I, Huang CFT, Yano M, Ma JF (2010) Gene limiting cadmium accumulation in rice. Proc Natl Acad Sci USA 107:16500-16505. doi:10.1073/pnas.1005396107

Ueno D, Koyama E, Yamaji N, Ma JF (2011) Physiological, genetic, molecular characterization of a high-Cd-accumulating rice cultivar, Jarjan. J Exp Bot 22:2265-2272. doi:10.1093/jxb/erq383

Upadhyaya H, Panda SK, Bhattacharjee MK, Dutta S (2010) Role of arbuscular mycorrhiza in heavy metal tolerance in plants: prospects for phytoremediation. J Phytol 2(7):16-27. doi:10.1093/jxb/erq383

Uraguchi S, Fujiwara T (2012) Cadmium transport and tolerance in rice: perspectives for reducing grain cadmium accumulation. Rice 5(5):1-8. doi:10.1186/1939-8433-5-5

Uraguchi S, Kamiya T, Sakamoto T, Kasai K, Sato Y, Nagamura Y, Yoshida A, Kyozuka J, Ishikawa S, Fujiwara T (2011) Lowaffinity cation transporter (OsLCT1) regulates cadmium transport into rice grains. Proc Natl Acad Sci USA 108(52):20959-20964. doi:10.1073/pnas.1116531109

Vaculík M, Landberg T, Greger M, Luxová M, Stoláriková M, Lux A (2012) Silicon modifies root anatomy, and uptake and subcellular distribution of cadmium in young maize plants. Ann Bot 110:433-443. doi:10.1093/aob/mcs039

Vandenhove H, van Hees M, van Winkel S (2001) Feasibility of phytoextraction to clean up low-level uranium-contaminated soil. Int J Phytoremediation 3:301-320. doi:10.1080/15226510108500061

Vassilev A, Lidon F (2011) Cd-induced membrane damages and changes in soluble protein and free amino acid contents in young barley plants. Emir J Food Agric 23(2):130-136

Verbruggen N, Hermans C, Schat H (2009) Molecular mechanisms of metal hyperaccumulation in plants. New Phytol 181(4):759-776. doi:10.1111/j.1469-8137.2008.02748.x

Vig K, Megharaj M, Sethunathan N, Naidu R (2003) Bioavailability and toxicity of cadmium to microorganisms and their activities in soil: a review. Adv Environ Res 8:121-135. doi:10.1016/S10930191(02)00135-1

Wahid A, Ghani A, Javed F (2008) Effect of cadmium on photosynthesis, nutrition and growth of mungbean. Agron Sustain Dev 28(2):273-280. doi:10.1051/agro:2008010

Wang AS, Angle JS, Chaney RL, Delorme TA, Reeves RD (2006) Soil $\mathrm{pH}$ effects on uptake of $\mathrm{Cd}$ and $\mathrm{Zn}$ by Thlaspi caerulescens. Plant Soil 281:325-337. doi:10.1007/s11104-005-4642-9

Wang MY, Chen AK, Wong MH, Qiu RL, Cheng H, Ye ZH (2011) Cadmium accumulation in and tolerance of rice (Oryza sativa L.) varieties with different rates of radial oxygen loss. Environ Pollut 159:1730-1736. doi:10.1016/j.envpol.2011.02.025

Wang W, Chen H, Wang A (2007a) Adsorption characteristics of Cd (II) from aqueous solution onto activated polygorskite. Sep Purif Tech 55:157-164. doi:10.1016/j.seppur.2006.11.015

Wang D, Jiang X, Rao W, He J (2009) Kinetics of soil cadmium desorption under simulated acid rain. Ecol Complex 6:432-437. doi:10.1016/j.ecocom.2009.03.010

Wang FY, Wang H, Ma JW (2010) Adsorption of cadmium (II) ions from aqueous solution by a new low-cost adsorbent - bamboo charcoal. J Hazard Mater 177:300-306. doi:10.1016/j.jhazmat.2009.12.032
Wang YQ, Zhu SY, Wang Y, Zhang MY (2007b) Tissue and inducible expression of a rice glutathione transporter gene promoter in transgenic Arabidopsis. Bot Stud 48:35-41

Wani PA, Khan MS, Zaidi A (2007) Cadmium, chromium and copper in green gram plants. Agron Sustain Dev 27(2):145-153. doi:10.1051/agro: 2007036

WHO (1992) Cadmium. World Health Organization Environmental Health Criteria, No. 134; Geneva, Switzerland

Williams LE, Pittman JK, Hall JL (2000) Emerging mechanisms for heavy metal transport in plants. Biochim Biophys Acta 1465:104 126. doi:10.1016/S0005-2736(00)00133-4

Wright DP, Scholes JD, Read DJ (1998) Effects of VA mycorrhizal colonization on photosynthesis and biomass production of Trifolium repens L. Plant Cell Environ 21(2):209-216. doi:10.1046/j.1365-3040.1998.00280.x

Wuana RA, Okieimen FE (2011) Heavy Metals in contaminated soils: a review of sources chemistry, risks and best available strategies for remediation, ISRN Ecology, vol. 2011, Article ID 402647, 20 pages, 2011. doi:10.5402/2011/402647.

Xue D, Chen M, Zhang G (2009) Mapping of QTLs associated with cadmium tolerance and accumulation during seedling stage in rice (Oryza sativa L.). Euphytica 165:587-596

Yan Y, Choi D, Kim D, Lee B (2010) Genotypic variation of cadmium accumulation and distribution in rice. JCSB 13(2):69-73. doi:10.1007/s12892-010-0036-5

Yang QW, Lan CY, Wang HB, Zhuang P, Shu WS (2006) Cadmium in soil-rice system and health risk associated with the use of untreated mining wastewater for irrigation in Lechang, China. Agric Water Manag 84:147-152. doi:10.1016/j.agwat.2006.01.005

Yeh CM, Hsiao LJH, Hsiao HJ (2004) Cadmium activates a mitogenactivated protein kinase gene and MBP kinases in rice. Plant Cell Physiol 45(9):1306-1312. doi:10.1093/pcp/pch135

Yu LH, Umeda M, Liu JY, Zhao NM, Uchimiya H (1998) A novel MT gene of rice plants is strongly expressed in the node portion of the stem. Gene 206(1):29-35. doi:10.1016/ S0378-1119(97)00577-5

Yu H, Wang JL, Wei F, Yuan JG, Yang ZY (2006) Cadmium accumulation in different rice cultivars and screening for pollution-safe cultivars of rice. Sci Total Environ 370:302-309. doi:10.1016/ j.scitotenv.2006.06.013

Yuan L, Yang S, Liu B, Zhang M, Wu K (2012) Molecular characterization of a rice metal tolerance protein, OsMTP1. Plant Cell Rep 31(1):67-79. doi:10.1007/s00299-011-1140-9

Zhan J, Wei S, Niu R, Li Y, Wang S, Zhu J (2012) Identification of rice cultivar with exclusive characteristic to $\mathrm{Cd}$ using a field-polluted soil and its foreground application. Environ Sci Pollut Res. doi:10.1007/s11356-012-1185-5

Zhang J, Sun W, Li Z, Liang Y, Song A (2009) Cadmium fate and tolerance in rice cultivars. Agron Sustain Dev 29:483-490. doi:10.1051/agro/2009008

Zhao FJ, Lombi E, McGrath SP (2003) Assessing the potential for zinc and cadmium phytoremediation with the hyperaccumulator Thlaspi caerulescens. Plant Soil 249:37-43. doi:10.1023/ A:1022530217289

Zhao FJ, Shewry PR (2011) Recent developments in modifying crops and agronomic practice to improve human health. Food Policy 36:94-S101. doi:10.1016/j.foodpol.2010.11.011 